\title{
SITUAÇÃO FUNDIÁRIA E CONSERVAÇÃO DE IMÓVEIS EM CENTROS HISTÓRICOS: O CASO DO BAIRRO DA CIDADE VELHA - BELÉM (PA)
}

\section{LAND LOCATION AND CONSERVATION OF PROPERTY IN HISTORIC CENTERS: THE CASE OF THE BAIRRO DA CIDADE VELHA - BELÉM (PA)}

\section{RESUMO}

\author{
Helena Lúcia Zagury Tourinho ${ }^{1}$ \\ Ana Beatriz Fernandes de Macedo² \\ Patrick Dhones Oliveira Alves ${ }^{3}$ \\ Marco Aurélio Arbage Lobo ${ }^{4}$
}

O artigo investiga a relação entre a situação fundiária e a condição da ocupação do lote, o uso do solo e o estado de conservação dos imóveis em áreas tombadas, a partir do estudo de um bairro inserido no Centro Histórico de Belém (CHB). Baseado em pesquisas bibliográficas e documentais e usando geoprocessamento, traça o histórico e o perfil da situação fundiária atual dos imóveis, quantifica e mapeia as características e os regimes de propriedade encontrados. Além disso, discute o papel do conflito entre municipalidade e União em torno dos terrenos de marinha e acrescidos na gestão do patrimônio fundiário e histórico. Constata que: (i) $55,85 \%$ da área e $44,79 \%$ dos imóveis carecem de informação sobre a situação fundiária; (ii) dos imóveis com informações, o traspasse é o tipo de alienação predominante (41,5\%); (iii) os imóveis traspassados e aforados, apresentam melhor conservação do que os alienados por resgate; (iv) o grau de conservação dos imóveis é preocupante ao somar os percentuais de imóveis baldios, em ruínas, e com má e regular conservação (59,5\%). Conclui-se que esse quadro ainda pode ser revertido, destacando o papel da questão fundiária para a conservação urbana em sítios históricos tombados como o CHB.

Palavras-chave: Situação Fundiária; Gestão Fundiária; Centro Histórico; Cidade Velha; Centro Histórico de Belém.

\footnotetext{
${ }^{1}$ Arquiteta e Urbanista formada pela Universidade Federal do Pará (1983), Doutora em Desenvolvimento Urbano pela Universidade Federal de Pernambuco (2011). É pesquisadora e professora do Programa de PósGraduação em Desenvolvimento e Meio Ambiente Urbano e do curso de Arquitetura e Urbanismo da Universidade da Amazônia, onde coordena o Grupo de Pesquisa em Mercado Imobiliário em Centro Histórico (Módulo Belém). Afiliação: Universidade da Amazônia. ORCID: http://orcid.org/0000-0001-7588-1680. Email:helenazt@uol.com.br

2 Arquiteta e Urbanista formada pela Universidade da Amazônia (2017), Mestre e Doutoranda em Desenvolvimento e Meio Ambiente Urbano (2020) pela Universidade da Amazônia, onde integra o Grupo de Pesquisa de Mercado Imobiliário em Centro Histórico (Módulo Belém). Afiliação: Universidade da Amazônia. ORCID: http://orcid.org/0000-0002-4357-1001. E-mail:anabeatrizfmacedo@gmail.com

${ }^{3}$ Arquiteto e Urbanista formado pela Universidade da Amazônia (2020). Afiliação: Universidade da Amazônia. ORCID: https://orcid.org/0000-0003-3754-5533. E-mail:patrickdhones@gmail.com

4 Arquiteto e Urbanista formado pela Universidade Federal do Pará (1982), Doutor em Desenvolvimento Socioambiental pela Universidade Federal do Pará (1999). É analista de informações do Instituto Brasileiro de Geografia e Estatísticas (IBGE) desde 2012, e colaborador no Grupo de Pesquisa em Mercado Imobiliário em Centro Histórico (Módulo Belém). Afiliação: Instituto Brasileiro de Geografia e Estatísticas. ORCID: https://orcid.org/0000-0002-3366-4992 .E-mail:lobo2502@gmail.com
} 


\section{ABSTRACT}

The article investigates the relationship between the land situation and the condition of occupation of the lot, land use and the state of conservation of properties in listed areas, based on the study of a neighborhood located in the Historic Center of Belém ( $\mathrm{CHB}$ ). Based on bibliographic and documentary research and using geoprocessing, it traces the history and profile of the current land tenure situation of the properties, quantifies and maps the characteristics and property regimes found. In addition, it discusses the role of the conflict between the municipality and the Union over marine lands and added to the management of land and historical heritage. It finds that: (i) $55.85 \%$ of the area and $44.79 \%$ of the properties lack information on the land tenure situation; (ii) of properties with information, transfer is the predominant type of sale (41.5\%); (iii) properties transferred and transferred are better preserved than those sold by redemption; (iv) the degree of conservation of the properties is of concern when adding up the percentages of vacant properties, in ruins, and with poor and regular maintenance $(59.5 \%)$. It concludes that this situation can still be reversed, highlighting the role of the land issue for urban conservation in listed historic sites such as the CHB. Keywords: Land Situation; Land Management; Historic Center; Cidade Velha; Historic Center of Belém.

\section{INTRODUÇÃO}

O esvaziamento por parte de algumas atividades econômicas e a degradação física e ambiental em centros históricos tradicionais são fenômenos observados em muitas cidades brasileiras, com profundas repercussões na preservação do patrimônio cultural, arquitetônico, urbanístico e paisagístico urbano (TOURINHO, 2005; TOURINHO, 2007; DURÁN, 2006; CAVÉM; 2007; BRASIL, 2011; VILLAÇA, 2012; BERNARDINO; LACERDA, 2015).

A cidade de Belém, fundada no início do século XVII por colonizadores portugueses, que dispõe de um rico patrimônio histórico, arquitetônico, urbanístico e paisagístico não foge a essa regra. De acordo com Penteado (1968), já nos anos 1960, o Bairro da Cidade Velha - onde teve origem a ocupação urbana belenense - apresentava sinais de decadência física, processo que se aprofundou nas décadas seguintes.

Para preservar o patrimônio histórico e artístico condensado no centro de Belém, uma série de instrumentos legais foram instituídos: a Lei Municipal № 7.401/1988, que criou o Centro Histórico de Belém (CHB); a Lei Orgânica do Município de Belém de 1990, que promoveu o tombamento do CHB; mediante a Lei № 7.709/1994 o CHB foi delimitado e regulamentado e foram estabelecidos 
incentivos fiscais à preservação do patrimônio histórico. Além disso, com fins de revitalização, requalificação e/ou simplesmente de preservação física, vários planos e projetos foram elaborados e implementados no CHB, especialmente, a partir da segunda metade da década de 1970 (TRINDADE JR; AMARAL, 2006; BRITO, 2007; COHAB, 2009; TOURINHO; LIMA, 2015; CASTRO; TAVARES, 2016).

Não obstante, os processos de abandono, descaracterização, subutilização, deterioração de imóveis e espaços públicos, o esvaziamento do uso habitacional em algumas áreas do centro tradicional e mais antigo da cidade de Belém e a saída de diversas atividades econômicas para outras áreas da cidade também vêm sendo constatados em diversos estudos (TOURINHO; LIMA, 2015; LIMA, 2015; MACEDO, 2020; MERCÊS; TOURINHO; LOBO, 2014; LACERDA et al., 2018).

A ociosidade imobiliária e a degradação física no CHB têm sido atribuídas a diversos fatores, como: inadequação da oferta face às mudanças nos padrões da demanda por imóveis habitacionais e de comércio/serviços; limites impostos à adaptação dos imóveis pela legislação urbanística; restrições à atuação do capital imobiliário; dificuldades e altos custos de manutenção de prédios tombados; não adoção pela legislação, políticas urbanas e intervenções de abordagem socioespacial e que articule as dimensões estrutura, forma, função e processo; etc. (COHAB, 2009; FERREIRA, 2014; LIMA, 2015; TOURINHO; LIMA, 2015).

Existem poucos estudos, contudo, que relacionem esse quadro à situação da propriedade fundiária. No caso de Belém, foi identificado apenas o trabalho de Albuquerque e Ramos (2021), que apesar de ter o mérito de alertar para a necessidade de políticas de regularização fundiária como estratégia para ampliar a moradia digna e reduzir a ociosidade imobiliária no $\mathrm{CHB}$, não identificou os tipos de regime de propriedade fundiária no $\mathrm{CHB}$, não dimensionou estes tipos, nem os relacionou com as características de uso, ocupação e conservação dos imóveis.

A questão fundiária desempenha um papel fundamental na configuração do espaço urbano, com implicações na ocupação humana e no ambiente construído. No CHB assume papel, particularmente, relevante, pois, além dos limites impostos ao direito de edificar na propriedade pelo estatuto do tombamento, os processos de regularização fundiária aqui são complexos, em função das características históricas de formação da propriedade e do domínio dos terrenos de marinha, objetos de litígio entre Município e União, o que dificulta a gestão tanto do patrimônio fundiário como do patrimônio histórico.

Em vista disso, o artigo procura responder as seguintes questões: qual a situação fundiária dos imóveis do CHB? Existe relação entre a situação fundiária e a condição do imóvel, o tipo de uso e o estado de conservação das edificações do CHB? É possível vincular a gestão fundiária às políticas para a preservação do patrimônio histórico? 
O artigo está estruturado em quatro partes, além dessa introdução. A primeira expõe o recorte espacial e a metodologia de levantamento de dados adotados. A segunda analisa a evolução histórica e legal da propriedade fundiária e seus rebatimentos no CHB. A terceira apresenta e discute os resultados da pesquisa relacionando a situação fundiárias com as condições de uso, ocupação e estado de conservação dos imóveis. Por fim, são expostas as principais conclusões acerca do assunto.

\section{CONSIDERAÇÕES METODOLÓGICAS}

O tombamento foi instituído pelo Decreto-Lei № 25/1937 como um dos principais instrumentos de intervenção do Poder Público sobre a propriedade privada ou pública, para contrabalançar os direitos - privados ou coletivos - de aproveitamento econômico e de uso, com a preservação de bens móveis e imóveis (FERNANDES; ALFONSIN, 2010).

De acordo com Forte (2015), a aplicação do instrumento do tombamento, com fins de preservação em Belém, pode ser subdividida em três momentos: o primeiro, compreendido entre as décadas de 1930 e 1960, em que os tombamentos se voltaram para edificações e monumentos individuais; no segundo, que abrange as décadas de 1960 a 1980, quando os tombamentos se voltam para os conjuntos paisagísticos, com inclusão dos entornos à leitura dos monumentos; e no terceiro momento, iniciado na década de 1990, quando o tombamento é visto no sentido amplo e é tombado o Centro Histórico de Belém pela já referenciada Lei Municipal no 7.709/1994.

Para o estudo de caso ora apresentado, foi escolhida a área tombada da Cidade Velha inserida no CHB por ser a de ocupação mais antiga, estando sujeita a regimes de propriedade estabelecidos desde a fundação da cidade e por abranger vasto patrimônio cultural, evidenciando questões territoriais passadas junto a práticas sociais e intervenções urbanas atuais relacionadas à preservação do patrimônio histórico. Esta área, ressalte-se, comporta os imóveis e respectivos entornos tombados pelo Governo do Estado do Pará (Lei no 5.629/1990) e está inserida, em grande parte, no conjunto arquitetônico, urbanístico e paisagístico tombado pelo Instituto do Patrimônio Histórico e Artístico Nacional (IPHAN), por meio da Portaria MINC no 54/2012¹.

O perímetro delimitado para fins do presente estudo é constituído pela Avenida 16 de Novembro, a Baía do Guajará, o Rio Guamá e a Av. Almirante Tamandaré. Esta área é integrada pelas Quadras 01 a 31 do Setor 01 do Mapa de Zonas de Bens Tombados e Unidades de Conservação da Companhia de Desenvolvimento e Administração da Área Metropolitana de Belém (CODEM) (Figura 1), que serviu de base para os levantamentos efetuados. 
Figura 1 - CHB, Bairro da Cidade Velha e Área de Estudo: Localização no Município de Belém.
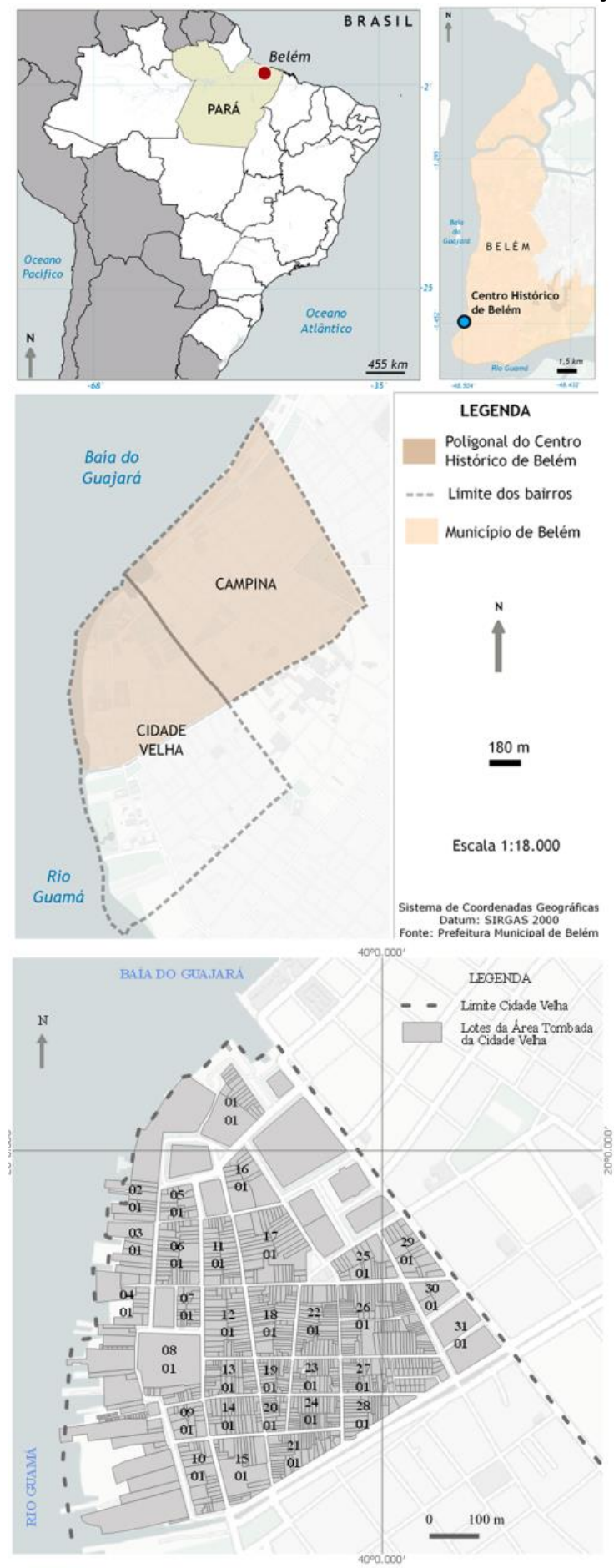

Fonte: Acervo da CODEM.

Elaboração: Ana Beatriz Macedo e Luiz Gusmão (2021).

A CODEM é uma empresa de economia mista constituída pela Prefeitura Municipal de Belém que tem, dentre seus objetivos, "planejar, coordenar, executar, monitorar e avaliar as atividades relacionadas à política municipal de regularização fundiária" (CODEM, 2014). Assim, a identificação da legislação fundiária que, ao longo da história, incidiu sobre a área de estudo, se fez, sobretudo, a partir de levantamentos no acervo e com o apoio do Núcleo de Prática Jurídica desta Companhia, 
que dirimiu dúvidas relacionadas aos termos de regulamentação utilizados - aplicações e jurisdições - nas tipologias de alienação adotadas, bem como às regulamentações existentes.

Os levantamentos de informações cadastrais realizados no período de julho a novembro de 2020 também foram executados nos arquivos fundiários da CODEM, que possui fichas de locação indicando os livros, denominados Termos Fundiários, em que estão registradas as situações fundiárias pelas quais o imóvel passou ao longo do tempo. Os documentos contidos nestes livros apresentam informações sobre a localização na quadra, a distância de esquina, a metragem e o nome dos proprietários dos lotes (em questão e confinantes). As informações coletadas foram sistematizadas em quadros, tabelas e mapeadas, compondo o sistema de informações geográficas criado para o presente trabalho.

Vale ressaltar que, ao lançar as informações coletadas nos livros, surgiram alguns entraves como: incompatibilidades entre o traçado original de quadra descrito nos Termos Fundiários e o observado na Planta de Referência Cadastral da CODEM; dificuldades de leitura diante da dilaceração física, pela ação do tempo, dos Termos Fundiários; inconsistências entre as informações presentes nos Termos Fundiários e as lançadas nas Fichas de Locação quanto aos nomes dos proprietários (do lote em questão e/ou dos confinantes), às metragens do lote e à locação do imóvel (distância de esquina e amarrações de locação). Diante da impossibilidade de realização de pesquisa patrimonial in loco para cada lote, a solução encontrada foi enquadrar estes imóveis na categoria sem informação fundiária.

Os levantamentos efetuados permitiram traçar o histórico fundiário, identificar e apontar as características dos principais regimes fundiários hoje existentes na área estudada, que são:

a) Propriedade Regularizada: a alienação de posse se encontra dentro dos parâmetros fundiários de regularização para cada tipo de alienação adotada pela CODEM (correspondências das metragens estabelecidas nos registros de alienação, identificação dos confinantes estabelecidos nos registros de alienação; registro no serviço de registro de imóveis; existência de aforamento, o ocupante do imóvel corresponde com a pessoa que está no registro). As propriedades regularizadas se encontram em diversas situações fundiárias (aforamento, traspasse, resgate de enfiteuse e ratificação de posse);

b) Propriedade em conflito fundiário: se encontra submetida a processo judicial pela posse da propriedade, conforme informação sobre o processo judicial contido na Ficha de Locação;

c) Propriedade desapropriada: cuja alienação fundiária procedida pela Prefeitura foi cancelada e a propriedade retornou para a esfera municipal; 
d) Propriedade sem informação de registro fundiário: necessita de pesquisa patrimonial e procedimentos de reconhecimento judicial para que se possa determinar ou não o seu proprietário ou regime fundiário.

Não se utilizou a categoria propriedade irregularizada ${ }^{2}$ para classificar os imóveis em desacordo com os parâmetros de regularidade estabelecidos pela CODEM, visto que o cadastro das propriedades do referido órgão não está atualizado, sendo necessário proceder o levantamento de campo, o que foi impossibilitado em razão da pandemia de COVID-19. Desse modo, os imóveis classificados como irregulares foram inseridos no grupo sem informação de registro fundiário.

Os dados referentes à condição do imóvel, ao uso do solo e ao estado de conservação da edificação foram coletados na Planta Cadastral produzida pela CODEM com base no Cadastro Técnico Municipal (CTM) de 2014 e no Boletim de Informações Cadastrais (BIC) do mesmo ano ${ }^{3}$. Tais informações foram atualizadas pela CODEM no ano de 2020.

As informações sobre as dimensões dos lotes dos BICs preenchidos foram comparadas com as registradas nos Termos de Regime Fundiário. Outras informações extraídas do BIC foram: $a$ condição do lote (baldio, sistema de recreio, edificado, em construção com lançamento predial, em construção sem lançamento predial e ruína); confinantes dos lados e fundo, para fins de checagem da localização e da posição do lote na quadra; uso do solo (residencial, comercial, industrial, serviços, religioso e outros); conservação do imóvel (boa, regular, má e ruínas).

Ao sistematizar as informações coletadas no BIC e compará-las com as informações dispostas na Planta de Referência Cadastral da CODEM, inconsistências foram identificadas, como: BICs antigos com informações que não correspondem à configuração espacial atual da quadra; incompatibilidades entre o código de inscrição imobiliária descrito no BIC e o existente em Planta Cadastral; desacordos nos alinhamentos dos lotes em relação à rua. Os lotes inclusos nessas situações foram enquadrados na categoria sem informações.

Superadas as dificuldades de classificação, os dados levantados no BIC foram cruzados com os obtidos nos levantamentos sobre a situação fundiária e sistematizados em mapas temáticos e tabelas cujos resultados são expostos e analisados a seguir.

\section{REGIMES DA PROPRIEDADE FUNDIÁRIA NO CHB}

A fundação de Belém, em 1616, foi marcada pela construção do Forte do Presépio (hoje Forte do Castelo) em um sítio com vista privilegiada para a Baía de Guajará e sua ocupação inicial esteve atrelada aos interesses de defesa e exploração econômica da região. A implantação da cidade seguiu diretrizes topográficas específicas, aproveitando as partes altas e contornando os acidentes 
geográficos, o que produziu grandes vazios desocupados em áreas alagadas ou alagáveis (CORRÊA, 1989; NORAT, 2007).

A formação fundiária urbana colonial no país ainda é pouco estudada. Ao analisar o caso de Belém, utilizando como referência a obra de Fonseca (2011), Fischer, Chambouleyron e Rocha (2017) mostram que a doação de terrenos às Câmaras para a constituição de "Bens do Concelho" era uma tradição portuguesa, segundo a qual uma parte das terras era destinada a uso comum (pastagens, logradouros, plantações comunais etc.) e outra poderia ser dividida e concedida aos habitantes, mediante contratos enfitêuticos, os aforamentos.

O tamanho dos patrimônios municipais era muito variado, podendo essas concessões sobrepor-se a outras concessões pré-existentes como sesmarias ou patrimônios religiosos ou mesmos restarem fragmentadas para não prejudicar direitos de terceiros. Sua constituição ocorria a partir de uma solicitação ao representante do rei, e para que tal doação se concretizasse, sua confirmação era necessária. Somente a partir dessa confirmação é que a Câmara estava legitimada a cobrar foro dos moradores (FISCHER, CHAMBOULEYRON, ROCHA 2017, p. 224).

Em 1627, o Senado da Câmara de Santa Maria de Belém do Grão-Pará recebeu, por delegação real do Governador Francisco Coelho de Carvalho, uma carta de doação de Sesmaria para incentivar o povoamento das terras e gerar receita para a municipalidade, pelo regime chamado de Aforamento. Atendia, assim, ao pedido de uma légua patrimonial feito pelos Oficiais da Câmara que alegavam que "por ocasião da fundação da cidade, em 1616, não se tinha alocado terras para ela, como era de costume" (FISCHER, CHAMBOULEYRON, ROCHA 2017, p. 225).

As terras sesmariais foram registradas no Livro I do Registro de Freguesia da Sé e demarcadas no ano de 1703, passando por sucessivas remarcações em 1851 e 1861 (MUNIZ, 1904; ÉLERES, 2014). Como mostram Fischer, Chambouleyron e Rocha (2017), embora não se tenha identificado o Ato de confirmação real da concessão de terras à Câmara de Belém, vários documentos oficiais da época, incluindo correspondências entre a Coroa Portuguesa e o Capitão Geral do Estado do Maranhão, permitem inferir que "o poder central reconhecia o domínio da Câmara sobre a légua da terra", estendendo-se, também, "aos terrenos sob influência das marés, salvo se estivessem afetados ao uso da Coroa para fins de navegação e defesa" (FISCHER, CHAMBOULEYRON, ROCHA 2017, p. 229).

A Figura 2 mostra que a área de estudo, assim como todo o conjunto do $\mathrm{CHB}$, insere-se na Primeira Légua Patrimonial de Belém. Portanto, o recorte espacial estudado está submetido ao regime de sesmarias e aforamentos da Prefeitura Municipal de Belém. Esta área, nos anos 1970 passou a integrar o capital social e a ter sua gestão realizada pela CODEM. 
Figura 2 - Primeira Légua Patrimonial de Belém, CHB, bairro da Cidade Velha e Área de Estudo.

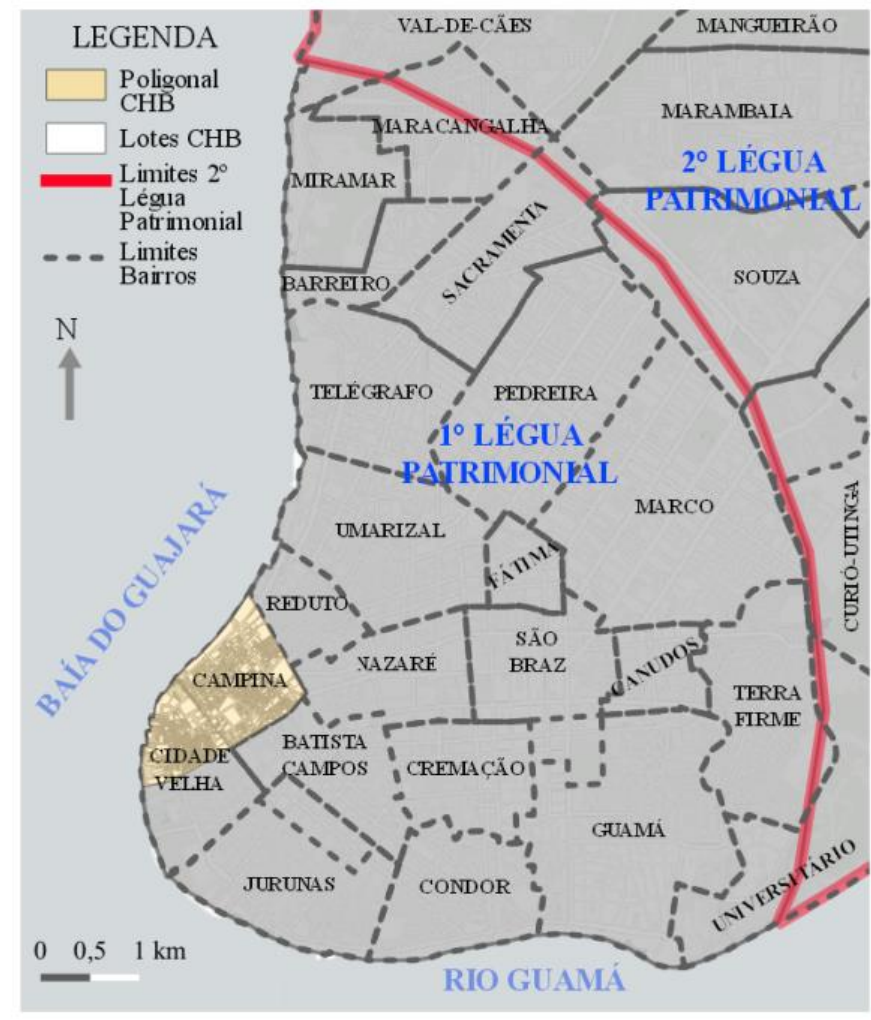

Fonte: Acervo da CODEM.

Elaboração: Ana Beatriz Macedo e Patrick Alves (2021).

Ressalte-se que, no contexto colonial brasileiro, as Cartas de Sesmaria, até 1710, não faziam menção à faixa de contato com o mar ou rios navegáveis, ficando implícito que eram bens sujeitos às Ordens Régias e Provisões da Coroa. A primeira vez em que se mencionam os terrenos de marinha e acrescidos como bens da União em um instrumento legal foi no art. 30 do Decreto no 24.643 , de 10 de junho de 1934, conhecido como Código de Águas (BRASIL, 1934).

A partir do Decreto-Lei no 9.760/1946, os terrenos de marinha e acrescidos foram definidos:

Art. 2 - São terrenos de marinha, em uma profundidade de 33 (trinta e três) metros, medidos horizontalmente, para a parte da terra, da posição da linha da preamar média de 1831:

os situados no continente, na costa marítima e nas margens dos rios e lagoas até onde se faça sentir influência das marés;

b) os que contornam as ilhas situadas em zona onde se façam sentir a influência das marés.

Parágrafo único. Para os efeitos deste artigo a influência das marés é caracterizada pela oscilação periódica de 5 (cinco) centímetros... do nível das águas, que ocorra em qualquer época do ano.

Art. 3 São terrenos acrescidos de marinha os que se tiverem formado, natural ou artificialmente, para o lado do mar ou dos rios e lagoas, em seguimento aos terrenos de marinha (BRASIL, 1967).

Por entender que os terrenos de marinha e seus acrescidos não foram doados pela Cora Portuguesa à Câmara, e que é a sucessora do Rei após a proclamação da República, a União começou 
a demarcar terras e a litigar com a Prefeitura de Belém sobre a dominialidade dessas áreas a partir de 1996.

A questão fundiária na área de estudo e no CHB como um todo ficou, territorialmente, segmentada em duas situações: uma faixa de orla compreendendo os terrenos de marinha e acrescidos, que se tornou objeto de conflito de dominialidade entre União e Prefeitura; e outra área que seguiu sob o domínio e gestão municipal (Figura 3).

Figura 3 - A área de estudo e a delimitação dos terrenos de marinha.

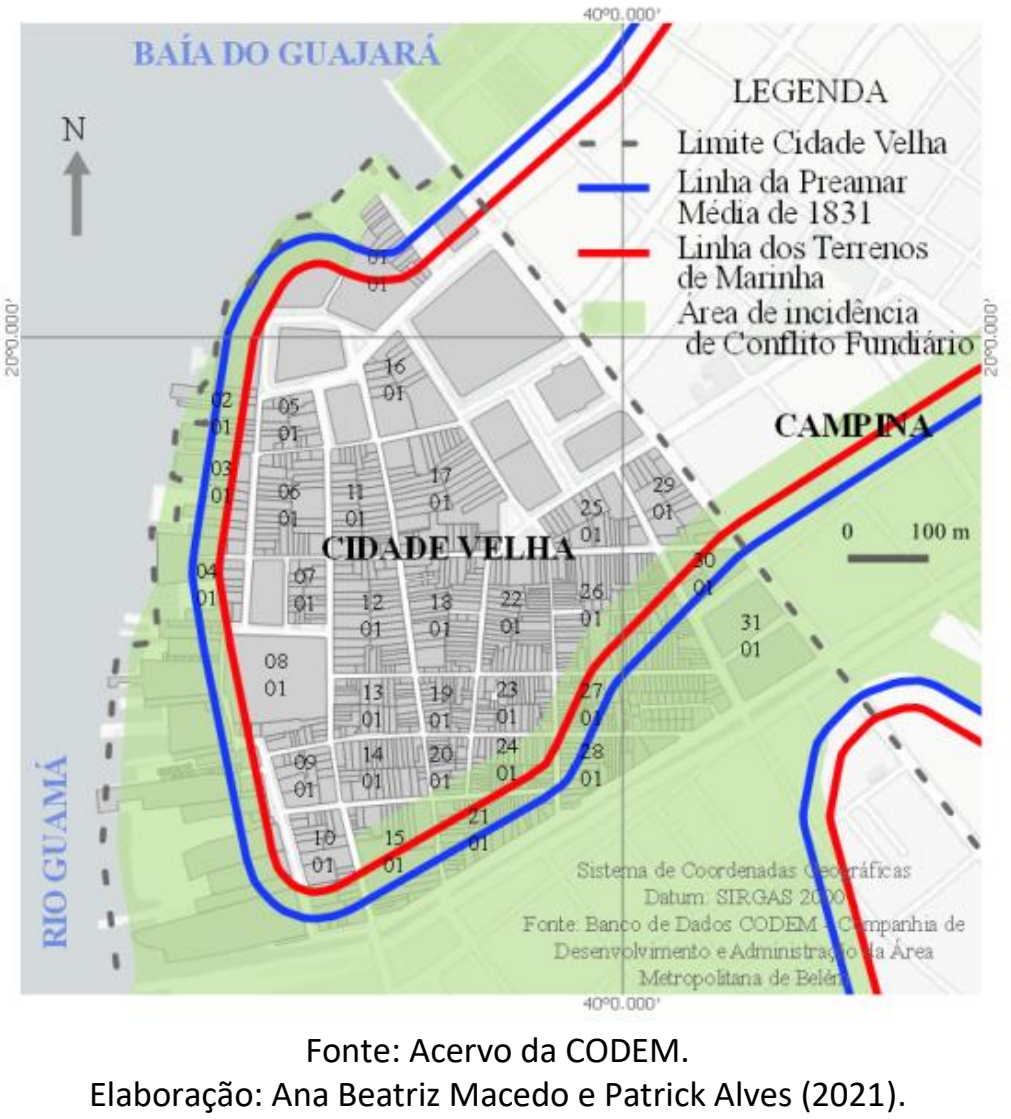

Nos terrenos de marinha e acrescidos, por força do artigo 77 da Lei no 5.172 de 1966 (Código Tributário Nacional), os lotes ficaram sujeitos ao pagamento de taxa de ocupação à União e tributo à Prefeitura (BRASIL,1966). Segundo Éleres (2014), neste caso, inexiste bitributação, vez que um pagamento é devido ao tributo e outro é derivado de taxa. O autor argumenta, ainda, que a cobrança de taxas pela União só se justificaria se o poder público oferecesse benfeitorias e compensações, o que no geral não ocorre, visto que os serviços ofertados nessas áreas vêm da municipalidade e/ou dos Estados, a exemplo do que ocorre no CHB.

No que concerne ao regime fundiário dos terrenos de marinha e acrescidos, a Lei Federal no 9.636/1998 estabelece que a ocupação possa ser efetuada nos seguintes regimes: aforamento (oneroso ou gratuito), cessão, concessão de direito real de uso (CDRU), concessão de uso especial 
para fins de moradia (CUEM), permissão de uso (temporário), permuta e alienação (venda) (BRASIL,1998).

O aforamento oneroso consiste no repasse do domínio útil ao contratante com a condição de pagamento de foros anuais, o que confere o direito de posse, uso, gozo e transmissão do imóvel por sucessão ou alienação. Se o senhorio de direito (União) não quiser exercer a preferência terá direito ao laudêmio, ou seja, uma porcentagem sob a transação de direito definitivo de ocupação, a qual poderá variar entre $2,5 \%$ e $100 \%$ do valor total do imóvel. Diante da possibilidade de o laudêmio ser o valor integral do negócio, perde-se o interesse na venda e a enfiteuse acaba se resumindo a mera transferência de geração em geração.

Já o aforamento gratuito é aquele no qual o contratante é dispensado do pagamento do valor de mercado do imóvel e ocorre quando o bem foi adquirido por terceiros ou em caso de sucessão hereditária, em consonância com o exposto pelo artigo 105 do Decreto-Lei no 9.760/1946 (BRASIL, 1967). O novo Código Civil brasileiro (CC/2002) vetou a cobrança do laudêmio, bem como impediu a criação de novas enfiteuses, apesar de não extinguir as já existentes. Ocorre que, esse dispositivo do CC/2002 não se aplica às enfiteuses de terras públicas e de terrenos de marinha, pois são regulados por lei especial, conforme o parágrafo 20 do art. 2.038 .

Portanto, diante das regras do Decreto Lei no 9.760/1946, o Poder Público continua podendo estabelecer enfiteuses de terras públicas, perante o pagamento anual de $0,6 \%$ sobre o valor atual do bem (BRASIL, 2002). A Prefeitura de Belém argumenta que as regras estabelecidas pela União para os aforamentos são inaplicáveis aos bens imóveis titulados pela Coroa Portuguesa antes da legislação sobre terrenos de marinha, cabendo à CODEM, o poder e o direito de regularizar a situação dos ocupantes nas áreas delimitadas pela poligonal da Primeira Légua Patrimonial, incluindo o recorte espacial estudado. Assim, a municipalidade aforou e doou terrenos das chamadas "áreas de baixada" em Belém nesse perímetro, a ocupação invadiu os acrescidos de marinha, inclusive em áreas de aterramentos feitos pelo Município em parceria com o Governo do Estado e modificou a paisagem urbana e a forma de apropriação.

A cessão de imóveis da União em Terrenos de marinha pode ser concedida aos Estados, Municípios, instituições educacionais, culturais e sociais, assim como às pessoas físicas e jurídicas, desde que seja para o benefício público, social ou para proveito econômico nacional, conforme art. 18 da Lei 9.636/1998 (BRASIL, 1998). Tal cessão é feita de forma gratuita ou em condições especiais.

De acordo com o art. 4ํ do Estatuto da Cidade (Lei no 10.257/2001), a concessão de direito real de uso (CDRU) deve ser utilizada como instrumento de regularização fundiária e política urbana (BRASIL, 2001). A concessão de uso especial para fins de moradia (CUEM) também é prevista no Estatuto da Cidade, como mecanismo de regularização fundiária, sobretudo, em assentamentos 
informais, a exemplo das áreas de "baixadas" em acrescidos de marinha. Sobre a concessão de uso especial de que trata o § 10 do art. 183 da Constituição prevê que:

Art. 183 Aquele que, até 22 de dezembro de 2016, possuiu como seu, por cinco anos, ininterruptamente e sem oposição, até duzentos e cinquenta metros quadrados de imóvel público situado em área com características e finalidade urbanas, e que o utilize para sua moradia ou de sua família, tem o direito à concessão de uso especial para fins de moradia em relação ao bem objeto da posse, desde que não seja proprietário ou concessionário, a qualquer título, de outro imóvel urbano ou rural. (Redação dada pela lei no 13.465, de 2017)

$\S 10$ A concessão de uso especial para fins de moradia será conferida de forma gratuita ao homem ou à mulher, ou a ambos, independentemente do estado civil.

$\S 200$ direito de que trata este artigo não será reconhecido ao mesmo concessionário mais de uma vez.

$\S 30$ Para os efeitos deste artigo, o herdeiro legítimo continua de pleno direito, na posse de seu antecessor, desde que já resida no imóvel por ocasião da abertura da sucessão (BRASIL, 2001).

A permissão de uso é dada em situações de título precário decorrente de fato episódico, ou seja, para casos de utilização de imóveis da União destinados a eventos de breve duração. A permuta de imóveis da União é tratada na jurisprudência do art. 30 da Lei no 9.636/1998 que, porém, não menciona os terrenos de marinha. Isso não impede que sejam permutados, todavia, é necessário ressaltar a característica física especial, o que tornaria o instituto da permuta inaplicável (ÉLERES, 2014).

A venda de imóveis da União está prevista nos artigos 22 e 29 da Lei no 9.636/1998. A Lei no 8.666/1993, em seu art. 17, ao tratar da alienação dos bens da administração pública estabelece que:

Art. 17. A alienação de bens da Administração Pública, subordinada à existência de interesse público devidamente justificado, será precedida de avaliação e obedecerá às seguintes normas:

[...]

f) alienação gratuita ou onerosa, aforamento, concessão de direito real de uso, locação ou permissão de uso de bens imóveis residenciais construídos, destinados ou efetivamente utilizados no âmbito de programas habitacionais ou de regularização fundiária de interesse social desenvolvidos por órgãos ou entidades da administração pública; (Redação dada pela Lei no 11.481, de 2007) (BRASIL,1993).

De acordo com os acervos fundiários e cadastrais da CODEM, os regimes de propriedade encontrados na área de estudo são: aforamento, traspasse, resgate de enfiteuse, ratificação de posse, desapropriação e conflito de posse.

Os Aforamentos são instituídos pela enfiteuse, mediante o domínio útil (direito ao uso do terreno e às benfeitorias construídas). Esses contratos podem ter sua titularidade (foreiro) transferida por meio do Traspasse. Outro regime de alienação fundiária estabelecido pela Instrução 
Normativa da CODEM № 1 de 11 de março de 2014 é o Resgate de Enfiteuse de Aforamentos inclusive de aforamentos constituídos anteriormente ao CC/2002 - caracterizados pela restituição do direito pleno do imóvel, caducando o contrato de enfiteuse e transferindo a posse para o adquirente através de outros regimes, como a Compra e Venda.

Salvo acordo entre as partes, os terrenos são resgatáveis 10 (dez) anos depois de constituídos, mediante pagamento de laudêmio de $2,5 \%$ (dois e meio por cento) sobre o valor atual da propriedade plena e de 10 (dez) pensões anuais pelo foreiro. Já as Ratificações de Posse, no contexto de administração da CODEM, são geralmente relacionadas a ações de inventário e herança, consolidando a posse de determinado imóvel.

As Desapropriações ocorrem quando os regimes fundiários são cancelados e a posse retorna para a municipalidade. Se os contratos fundiários tiverem em situação de inadimplência do pagamento dos foros, extinção de comisso, não averbação e inconsistências na cadeia dominical ou no registro de imóveis, eles são classificados como irregulares. Há ainda as situações de Conflito de Posse, onde os regimes fundiários apresentam discrepâncias na locação e alienação, geralmente, são alienações sem o reconhecimento do senhorio e incidência entre termos fundiários.

Os processos administrativos de demarcação de terras de marinha no Município de Belém se encontram relatados em Fischer (2017). Segundo a autora, tiveram início a partir do Processo Administrativo no 10280005431/94-34, em 1994. Ao final do procedimento, a SPU requereu, em seu nome, a validação do registro de demarcação perante o 10 Ofício de Registro de Imóveis, para que a União pudesse formalizar a concessão de uso em terrenos de 1ํ Légua Patrimonial, inclusive, no CHB (FISCHER, 2017; BORGES, 2012).

O 1 o Ofício de Registro de Imóveis questionou a solicitação à Corregedoria de Justiça da Região Metropolitana de Belém, declarando, mediante Ofício no 1oSRI/705/2011/SRI-PA, que a pretensão da União se sobrepunha às áreas correspondentes à 1ạ Légua Patrimonial, que estariam registradas como pertencentes à CODEM, incidindo em uma numerosa quantidade de imóveis particulares (FISCHER, 2017; BORGES, 2012). Em razão da referida alegação, a Desembargadora Dahil Paraense de Souza designou a continuidade do registro da área à CODEM. Em resposta à União, entrou com uma Ação Ordinária contra o 1o Ofício, solicitando o registro da área, porém, a ação foi revogada sem julgamento de mérito (FISCHER, 2017).

Em 2007, o Município de Belém ajuizou uma Ação Civil para a extinção do Processo Administrativo em tramitação desde 1994 e demais atos subsequentes de demarcação e incorporação ao patrimônio pela União relacionados à demarcação e à incorporação de áreas municipais pela União. Dois anos depois processou, por intermédio de Ação Cautelar Incidental à União, solicitando a paralização de todos os atos de regularização fundiária na poligonal da 1a Légua 
Patrimonial. A decisão sentenciada, em 2019, foi a extinção do processo, sem julgamento do mérito (BRASIL, 2019).

Devido ao litígio entre as partes, a CODEM, por intermédio da Resolução no 005/2012, interrompeu temporariamente a transferência de domínio pleno em acrescidos de marinha na 1a Légua Patrimonial de Belém (CODEM, 2012), ou seja, a regularização do domínio pleno na porção de terra próxima a Baía do Guajará e ao Rio Guamá até a o limite da linha vermelha, observada na Figura 3.

Para viabilizar acordos institucionais, o Município de Belém apresentou uma proposta à SPU de gestão compartilhada, visando desenvolver ações conjuntas destinadas à regularização fundiária de áreas em litígio, definindo estratégias para a regularização de áreas sub judice. $O$ aceite da proposta foi oficializado pelo Diário Oficial da União em 13 de fevereiro de 2012. Mas, na prática, as discussões não avançaram e, em 2014, a CODEM retomou de forma própria a regularização fundiária de processos e o resgate de aforamentos sobre a área (FISCHER, 2017).

A Lei no 13.240/2015 dispõe sobre a regularização do resgate de aforamento e novas maneiras de regularização fundiária em terrenos de marinha e acrescidos situados em áreas urbanas, orientando sobre a transferência de patrimônio aos municípios, conforme consta no Art. 15:

Art. 15. Ficam transferidos aos Municípios e ao Distrito Federal os logradouros públicos, pertencentes a parcelamentos do solo para fins urbanos aprovados ou regularizados pelo poder local e registrados nos cartórios de registro de imóveis, localizados em terrenos de domínio da União (BRASIL, 2015).

Apesar das tentativas de negociação e das alterações na legislação, até o fechamento do artigo, não foram equacionadas as questões específicas, referentes ao conflito judicial entre as partes na primeira légua patrimonial de Belém como um todo, nem no recorte espacial estudado.

Assim, como se pode constatar, as circunstâncias legais produzem uma dinâmica fundiária bastante complexa no $\mathrm{CHB}$, em especial na área de estudo, onde há o embate jurídico entre a Prefeitura Municipal de Belém e a União pela gestão fundiária das áreas de marinha. Como será apresentado na sequência, tal quadro fundiário se articula com a condição da ocupação do lote, com os usos do solo e com o estado de conservação física dos imóveis. 


\section{ANÁLISE DOS RESULTADOS}

\subsection{SITUAÇÃO FUNDIÁRIA NA ÁREA DE ESTUDO}

De acordo com as informações sistematizadas na Tabela 1, 54,78\% dos lotes (ou 532 lotes dos 971 pesquisados) estão inseridos em algum tipo de regime fundiário atualizado. Mais da metade da área total pesquisada, ou seja, 55,85\% da área do bairro da Cidade Velha no $\mathrm{CHB}$, correspondente a $44,79 \%$ dos lotes, contudo, não dispõem de informações atualizadas e precisas sobre a situação fundiária.

Tabela 1 - CHB - Bairro da Cidade Velha: Quantidade e área total de lotes segundo situação fundiária, 2020.

\begin{tabular}{|c|c|c|c|c|}
\hline \multirow{2}{*}{ SITUAÇÃO FUNDIÁRIA } & \multicolumn{2}{|c|}{ QUANTIDADE } & \multicolumn{2}{|c|}{ ÁREA } \\
\hline & LOTES & $\%$ & LOTES & $\%$ \\
\hline Com regime & 532 & 54,78 & 160.021 & 43,13 \\
\hline Com conflito & 4 & 0,41 & 3.732 & 1,06 \\
\hline Sem informação & 435 & 44,79 & 207.192 & 55,85 \\
\hline TOTAL & 971 & 100,0 & 370.945 & 100,0 \\
\hline
\end{tabular}

Fonte: Acervo fundiário da CODEM (2020).

Elaboração: Patrick Alves

Nota: Na categoria "sem informação" foram incluídas as praças.

Em que pese nesse grupo estarem inseridos os equipamentos públicos e religiosos de grande porte - como é o caso das Igrejas do Carmo, da Sé, de Santo Alexandre e de São João, bem como do Palácio Antônio Lemos, do Museu do Estado, da Assembleia Legislativa, do Instituto Histórico e Geográfico do Pará e muitos outros, merece destaque a grande quantidade de imóveis sem informações localizados na faixa de terrenos de marinha (Figura 4). Cabe enfatizar que, dentre os imóveis que não possuem informação fundiária, estão os edifícios religiosos que fizeram parte dos primeiros bens imóveis tombados individualmente pelo IPHAN, em 1940 (ALBUQUERQUE, RAMOS, 2021), o que indica que os órgãos responsáveis pela regularização fundiária e pelo patrimônio não atuam em conjunto para eliminar obstáculos à preservação. 
Figura 4 - CHB - Bairro da Cidade Velha: Distribuição espacial dos lotes por situação fundiária, 2020.

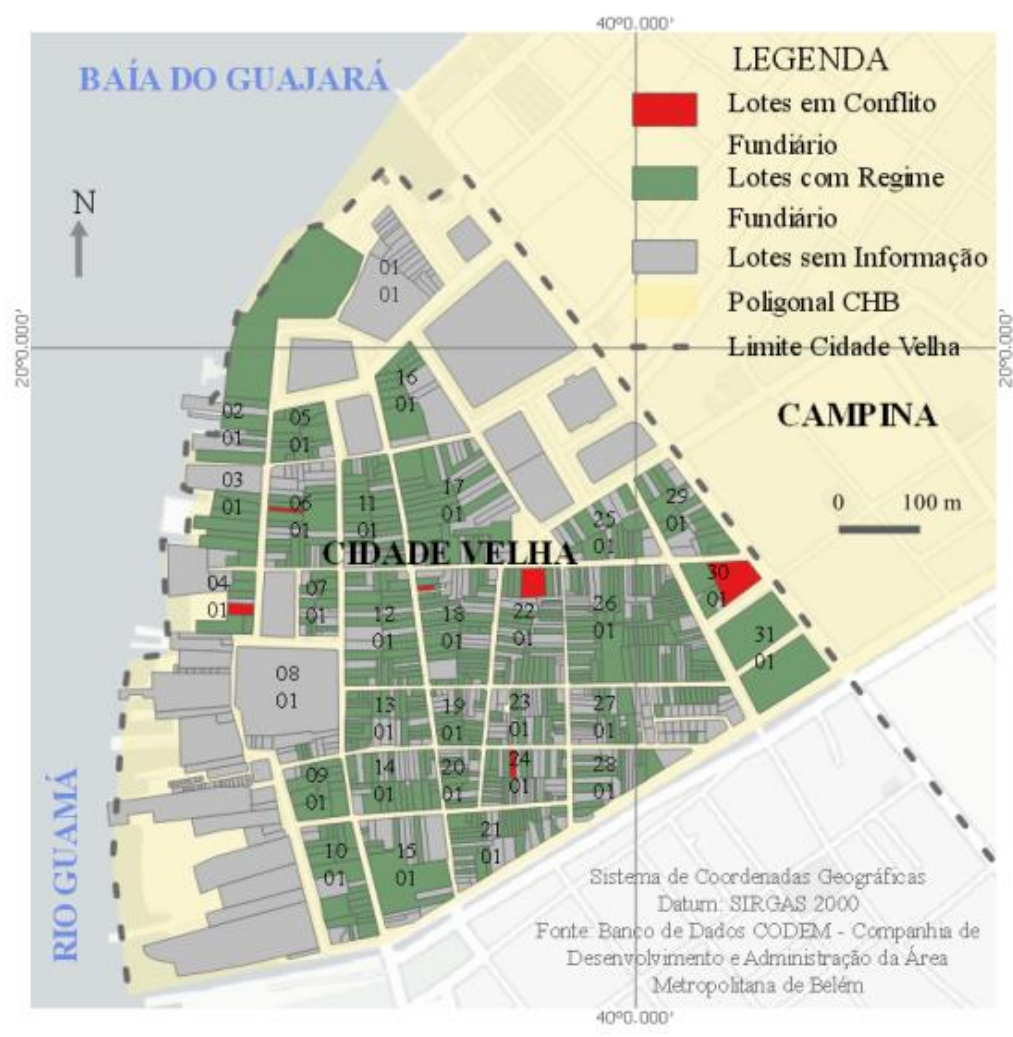

Fonte: Acervo da CODEM.

Elaboração: Ana Beatriz Macedo e Patrick Alves (2021), com base em informações levantadas por Patrick Alves.

Poucos lotes regularizados estão situados na área de orla e nos locais de antigos cursos d'água, pois a CODEM interrompeu o processo de Resgate e Compra e Venda de bens imóveis nos terrenos de marinha, em razão do embate judicial entre a União e a Municipalidade pela gestão do terreno. A lacuna de informações na faixa de sobreposição com os terrenos de marinha expõe a dificuldade da municipalidade de gerir não somente o patrimônio fundiário, mas também a gestão e fiscalização das intervenções no patrimônio histórico edificado, já que o registro regularizado de propriedade é requisito para aprovação de projeto e obtenção de alvará de obras junto aos órgãos competentes. Sem isso, o proprietário fica proibido de demolir ou construir, modificar, pintar ou restaurar a edificação.

Diferente do que se esperava inicialmente, os conflitos existentes na área são reduzidos a apenas $0,41 \%$ dos lotes, sendo que em pelo menos dois deles decorrem de processos judiciais relacionados à problemas de herança. A Tabela 2 apresenta os dados referentes à quantidade e área dos lotes de acordo com o regime fundiário. 
Tabela 2. CHB - Bairro da Cidade Velha: Quantidade de lotes segundo tipo de regime fundiário, 2020

\begin{tabular}{lrrrr}
\hline REGIME FUNDIÁRIO & \multicolumn{3}{c}{ QUANTIDADE } & \multicolumn{3}{c}{ ÁREA } \\
\cline { 2 - 5 } & LOTES & $\%$ & LOTES & $\%$ \\
\hline Traspasse & 403 & 41,5 & 112.718 & 30,38 \\
Aforamento & 35 & 3,6 & 9.535 & 2,57 \\
Resgate & 72 & 7,41 & 27.861 & 7,51 \\
Compra e venda & 0 & 0 & 0 & 0 \\
Ratificação de posse & 20 & 2,05 & 7.874 & 2,12 \\
Sem informação & 430 & 44,28 & 176.327 & 47,53 \\
Praça & 5 & 0,51 & 30.865 & 8,32 \\
Conflito de Posse & 4 & 0,41 & 3.732 & 1 \\
Desapropriações & 2 & 0,2 & 2.033 & 0,54 \\
\hline TOTAL & 971 & 100,0 & 370.945 & 100,0 \\
\hline
\end{tabular}

Fonte: Acervo fundiário da CODEM (2020).

Elaboração: Patrick Alves.

Nota-se, novamente, o peso dos lotes sem informação fundiária ao se analisar tanto a quantidade $(44,28 \%)$, quanto a área total $(47,53 \%)$ dos lotes levantados. Além disso, verifica-se que, dos lotes com regime fundiário $(54,78 \%)$, os Traspasses (41,5\%) respondem como o tipo de alienação imobiliária predominante. Vale considerar que o regime de Aforamento é a condição inicial para o Traspasse, que é o repasse dos aforamentos para terceiros ao longo do processo de alienação.

Somando-se os lotes com alienação de domínio útil - Aforamentos e Traspasses ${ }^{4}$ - tem-se que 438 imóveis, o que corresponde a $45,1 \%$ do total dos lotes, são advindos do sistema de enfiteuse ali consolidado. Assim sendo, em última instância, ainda é a Prefeitura Municipal de Belém a principal proprietária dos lotes regularizados na área de estudo. Se adicionadas as Desapropriações, esse número é ainda maior, uma vez que estes também são processos que devolvem a posse plena dos imóveis para o patrimônio do município.

Diante do exposto, entende-se que quase o total de lotes com aforamento já foi transferido mediante a alienação do domínio útil para terceiros, mas com o domínio pleno ainda sob tutela da municipalidade. Os dados sugerem, também, que o mercado imobiliário na área de estudo não se encontra congelado, mas é um mercado que transaciona, predominantemente, domínios úteis. Ademais, permitem supor a existência de tendência que, tão logo seja regularizada, parte dos terrenos venha a ser transacionada, mesmo que por Traspasse, ou seja, sem resgate da enfiteuse. É possível imaginar, inclusive, que a motivação para a regularização esteja no interesse do foreiro de transacionar o imóvel.

Quanto aos regimes que tratam da transferência do domínio pleno para terceiros, ou seja, os Resgates e Ratificações de Posse, 92 imóveis $(9,46 \%)$ saíram da administração pública para o patrimônio particular. Embora esse número ainda seja pouco expressivo, a tendência é que, um dia, os Traspasses sofram o procedimento de Resgate, resultando na alienação definitiva destes imóveis (hoje com contrato de alienação do domínio útil) para os respectivos proprietários. Contudo, 
também é possível que, como proprietária plena dos imóveis com termos de traspasses, a administração municipal promova a extinção da enfiteuse de imóveis abandonados ou subutilizados, resgatando para si o domínio útil desses lotes. Tal procedimento tornaria a Prefeitura proprietária definitiva (domínio útil e domínio pleno) desses imóveis, o que possibilitaria a gestão mais ampla do patrimônio fundiário e da preservação do patrimônio histórico nesses casos.

A Figura 5 apresenta a distribuição espacial dos lotes por regime da propriedade fundiária. A ausência de um padrão espacial na distribuição dos diversos tipos de regime fundiário regularizados, de certa forma, revela que, junto à dificuldade de equacionar os conflitos entre a Municipalidade e a União, são as demandas e os interesses particulares dos foreiros que regem essa distribuição.

Figura 5 - CHB - Bairro da Cidade Velha: Distribuição espacial dos lotes por regime da propriedade fundiária, 2020.

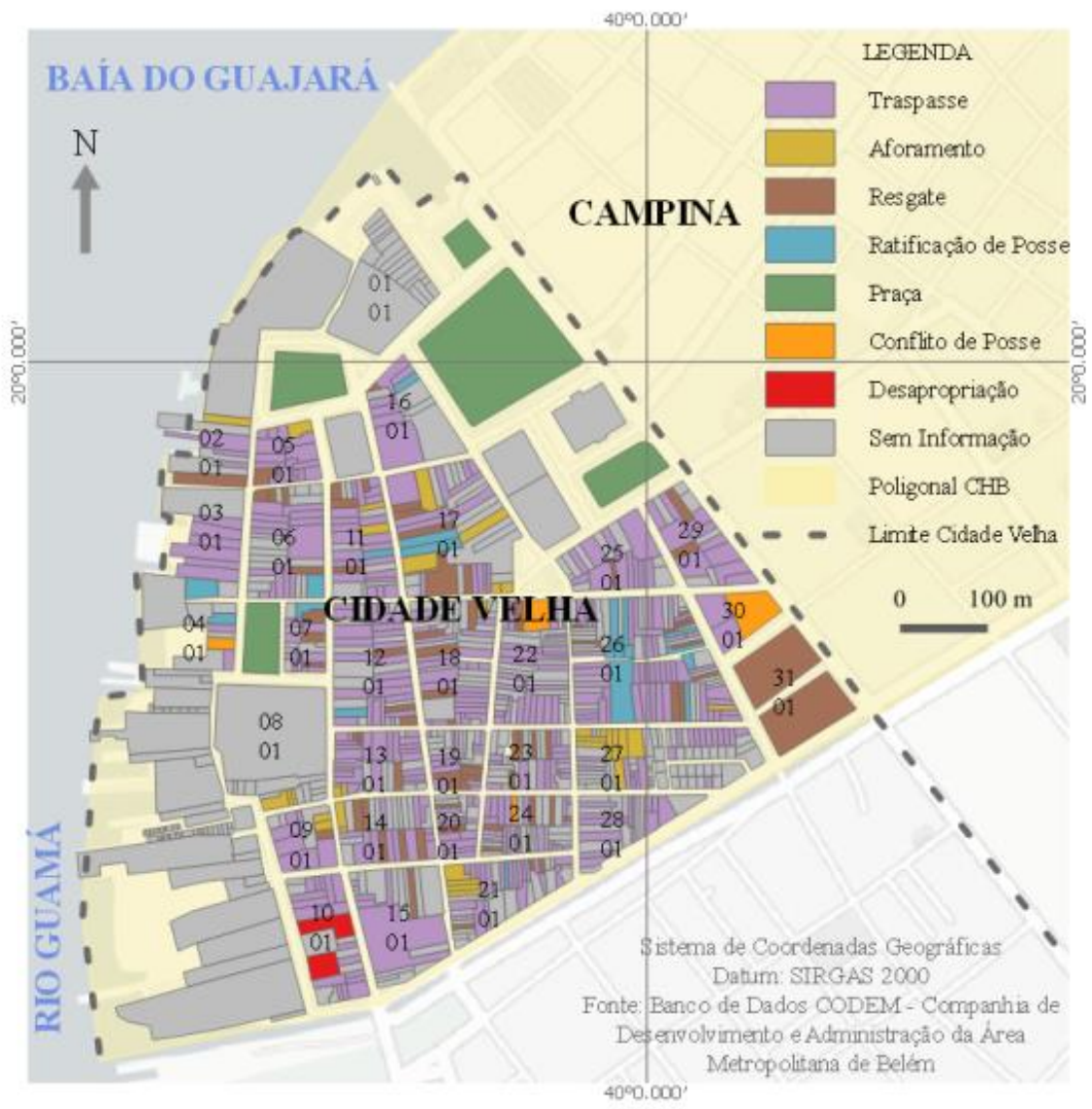

Fonte: Acervo da CODEM.

Elaboração: Ana Beatriz Macedo e Patrick Alves (2021) com base em informações levantadas por Patrick Alves.

\subsection{SITUAÇÃO FUNDIÁRIA E CONDIÇÃO DA OCUPAÇÃO DOS LOTES}

Para a análise da condição do lote foi considerada a classificação usada pela CODEM, ou seja: baldio, recreio, edificado, em construção e em ruínas ${ }^{5}$. Ao relacionar o regime fundiário com a 
condição dos lotes, encontra-se que quase a totalidade dos lotes da área de estudo é edificada (97,94\%), alcançando-se $100 \%$ em situações de ratificação de posse, desapropriação e conflito fundiário. (Tabela 3).

Tabela 3 - CHB - Bairro da Cidade Velha: Quantidade e percentual de imóveis por tipo de regime fundiário, segundo a condição da ocupação do lote, 2020.

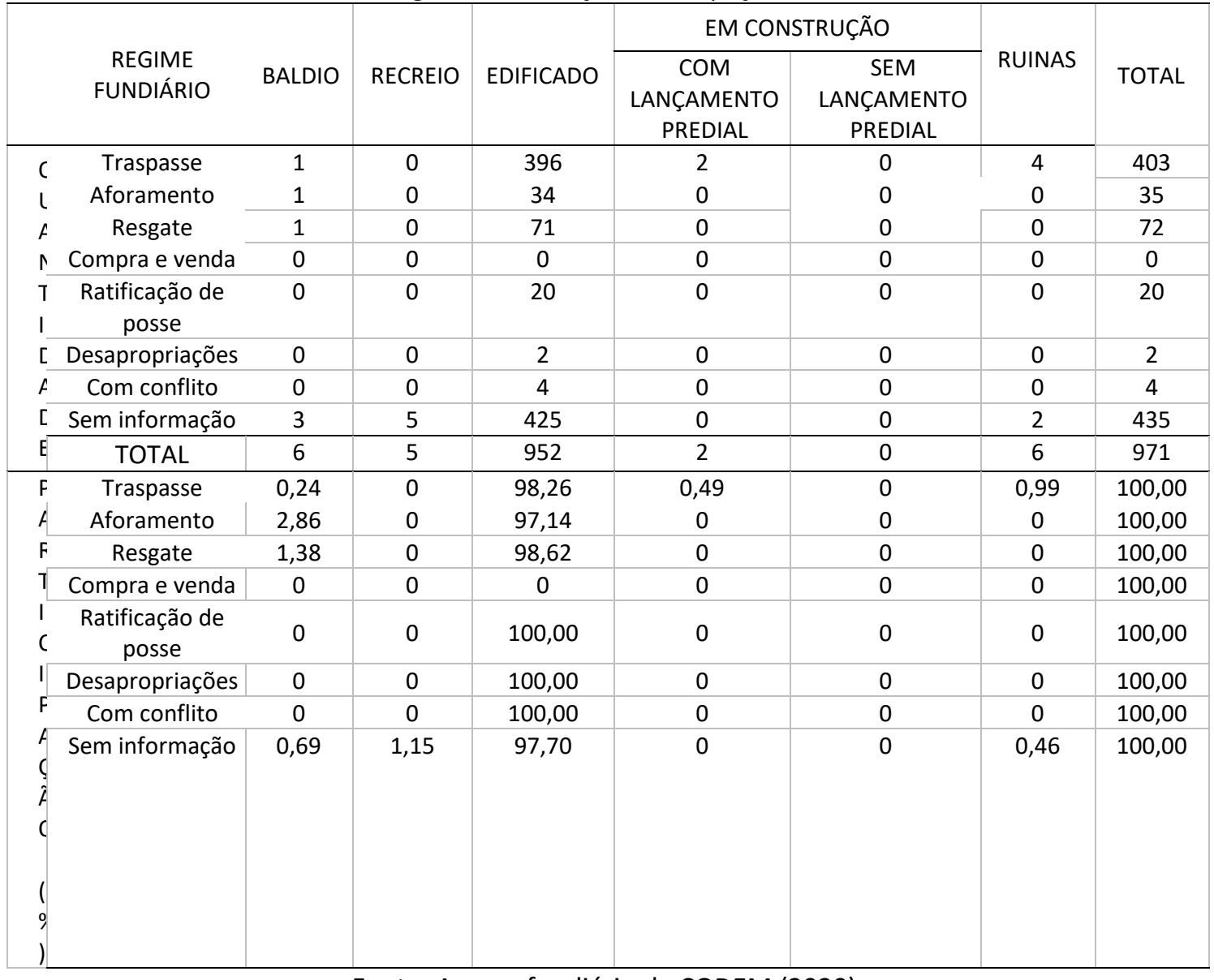

Fonte: Acervo fundiário da CODEM (2020).

Elaboração: Patrick Alves.

Nota: Na categoria "sem informação" foram incluídas as praças.

Os lotes edificados estão distribuídos em todo o bairro, como se nota na Figura 6, independente do regime fundiário. Os poucos lotes em construção ( 2 unidades) são lotes em regime de traspasse. Essa pequena quantidade evidencia que não há renovação de prédios expressiva na área de ocupação mais antiga da cidade.

Os lotes baldios ( 7 unidades) e em ruínas ( 6 unidades) aparecem nos regimes de traspasse ( 5 unidades), aforamento ( 1 unidade), resgate ( 2 unidades) e sem informação ( 5 unidades). 0 baixo número de ocupação nesse estado exprime que os níveis mais graves e irreversíveis de degradação (baldios e em ruínas) ainda são possíveis de serem controlados. Ressalte-se que os lotes baldios e em ruínas de maiores dimensões estão localizados na área de marinha, onde CODEM e SPU aguardam definição judicial. 
Figura 6 - CHB - Bairro da Cidade Velha: Distribuição espacial dos lotes de acordo com o regime fundiário e a condição da ocupação, 2020.
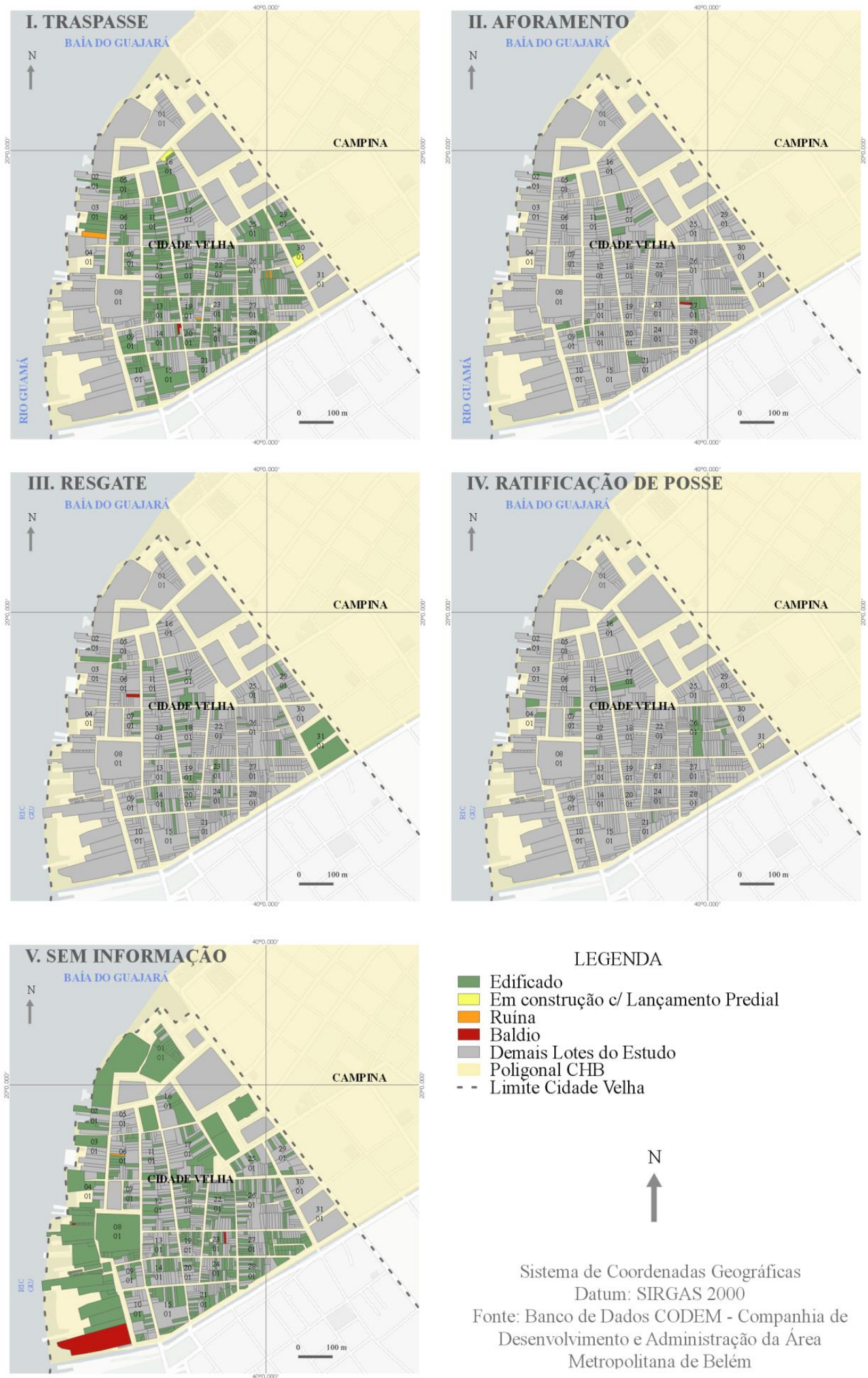

LEGENDA

Edificado

Em construção c/ Lançamento Predial

Ruina

- Baldio

Demais Lotes do Estudo

Poligonal CHB

- - Limite Cidade Velha

Fonte: Acervo da CODEM.

Elaboração: Ana Beatriz Macedo e Patrick Alves (2021) com base em informações levantadas por Patrick Alves. 


\subsection{SITUAÇÃO FUNDIÁRIA E USO DO SOLO}

O uso do solo foi classificado em: residencial, comercial, serviços, religioso, industrial, baldio e misto - sendo considerados mistos aqueles que conjugam usos distintos em um mesmo imóvel (por exemplo, comércio com residência, residência com serviços, etc.) - recreacional, ruína e outros. A Tabela 4 expõe os dados relativos ao uso do solo por situação fundiária dos imóveis e a Figura 7 apresenta a distribuição espacial dos usos do solo em geral e de acordo com o regime fundiário (traspasse, aforamento, resgate, ratificação de posse e sem informação).

O uso residencial concentra-se no interior do polígono de estudo e corresponde a mais da metade dos lotes levantados. O uso comercial e de serviço se faz presente nas regiões de escassez de habitações, como é o caso da orla, caracterizada como terreno de Marinha. Nos demais terrenos, a mistura de usos predomina com a distribuição dispersa dos imóveis de comércio e serviços.

O uso residencial é, indubitavelmente, predominante na área de estudo, sendo majoritário tanto nos imóveis com registro fundiário, quanto nos sem informações. Além disso, é o que possui maior participação percentual entre os imóveis que foram transacionados o domínio útil e a alienação plena, como mostram as informações das Ratificações de Posse (55\%) e Resgates (80,55\%). As exceções a essa regra são apenas os lotes em conflitos, onde dominam os lotes com usos terciários (comércio e serviços).

As atividades de comércio e serviço também se encontram presentes e são expressivas na área de estudo, estando concentradas, sobretudo, na orla onde funcionam portos, lojas de equipamentos náuticos, depósitos, bares e casas de shows e outros (Figura 7). No restante da área, os estabelecimentos terciários se localizam de maneira dispersa, não raras vezes associados a usos residenciais, o que contribui para o aumento da vitalidade na área.

O uso misto ocorre em imóveis traspassados, resgatados e sem informações sobre o regime fundiário. O uso misto do tipo comercial/residencial destaca-se na Rua Dr. Assis, via com grande fluxo de veículos e pedestres, e um dos principais corredores de transporte coletivo da área de estudo. Outro uso presente diz respeito ao uso industrial que se apresenta disperso em toda a área (Figura 7). 
Figura 7 - CHB - Bairro da Cidade Velha: Distribuição espacial dos lotes de acordo com o regime fundiário e o uso do solo, 2020.
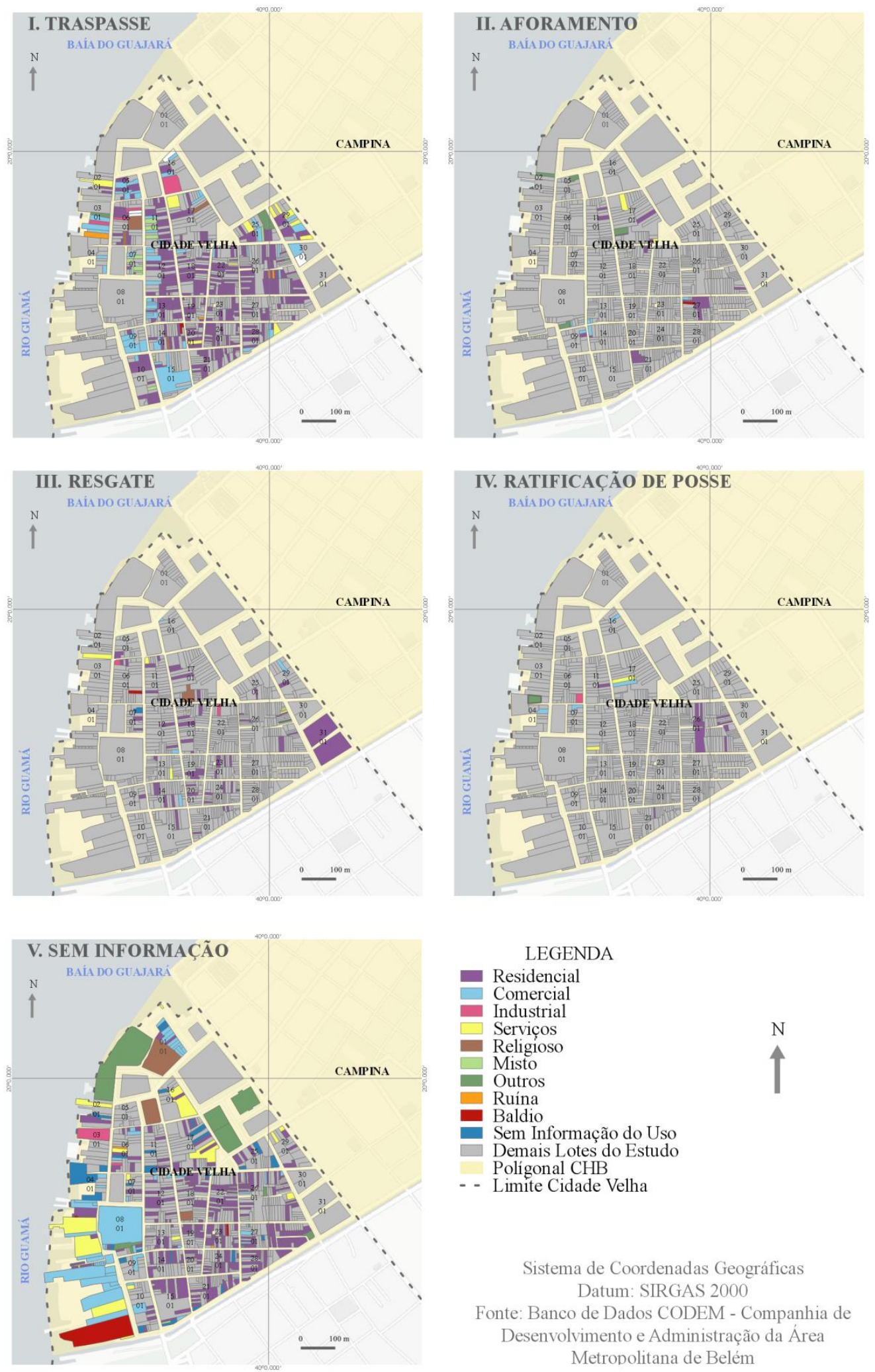

Fonte: Acervo da CODEM.

Elaboração: Ana Beatriz Macedo e Patrick Alves (2021) com base em informações levantadas por Patrick Alves. 
Tabela 4 - CHB - Bairro da Cidade Velha: Quantidade e percentual de lotes por tipo de regime fundiário, segundo o uso do solo, 2020.

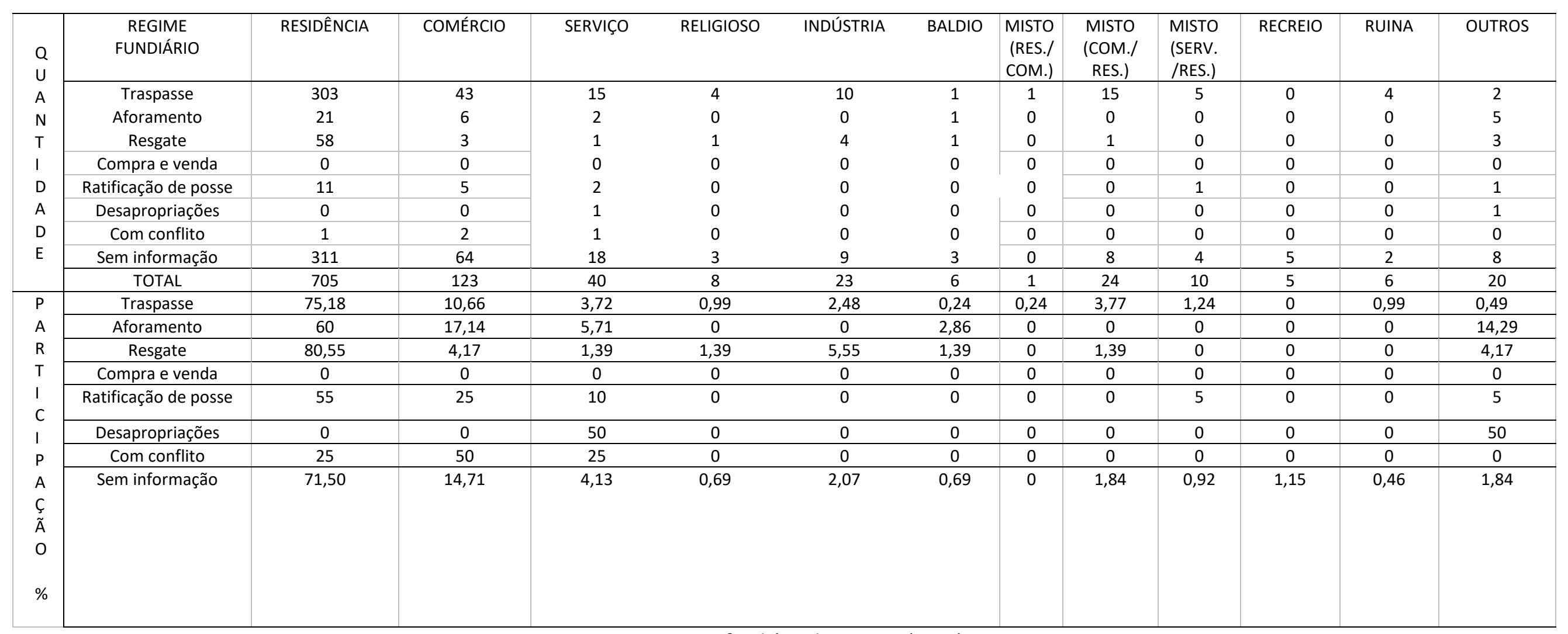

Fonte: Acervo fundiário da CODEM (2020).

Elaboração: Patrick Alves.

Nota: Na categoria "sem informação" foram incluídas as praças. 


\subsection{SITUAÇÃO FUNDIÁRIA E ESTADO DE CONSERVAÇÃO DO IMÓVEL}

O estado de conservação do imóvel é considerado, conforme o Boletim Imobiliário Cadastral da CODEM: bom - quando pintura, pisos, paredes, telhados não apresentam sinais visíveis de desgastes, encontrando-se com aparência de novos; regular - quando pintura, pisos, paredes, telhados apresentam sinais visíveis de desgastes, encontrando-se com aparência de usados; e mau, quando a edificação apresenta rachaduras e infiltrações, com paredes, pisos e pinturas com aparências desgastadas.

Quanto à análise do estado de conservação dos imóveis da área de estudo, os dados coletados apontaram para a significativa ocorrência de edificações em bom $(39,03)$ ou regular $(42,73 \%)$ estado de conservação, o que totaliza cerca de $81 \%$ das edificações em condições aceitáveis (Tabela 5).

Tabela 5 - CHB - Bairro da Cidade Velha: Quantidade e percentual de lotes por tipo de regime fundiário, segundo estado de conservação, (valores percentuais) 2020.

\begin{tabular}{|c|c|c|c|c|c|c|c|c|}
\hline & REGIME FUNDIÁRIO & BOM & REGULAR & MAU & BALDIO & RUINAS & S/INF. & TOTAL \\
\hline \multirow{9}{*}{$\begin{array}{c}\text { Q } \\
\text { U } \\
\text { A } \\
\text { NT } \\
\text { ID } \\
\text { A } \\
\text { DE }\end{array}$} & Traspasse & 172 & 164 & 59 & 1 & 4 & 3 & 403 \\
\hline & Aforamento & 15 & 14 & 4 & 1 & 0 & 1 & 35 \\
\hline & Resgate & 19 & 36 & 14 & 1 & 0 & 2 & 72 \\
\hline & Compra e venda & 0 & 0 & 0 & 0 & 0 & 0 & 0 \\
\hline & $\begin{array}{l}\text { Ratificação de } \\
\text { posse }\end{array}$ & 12 & 6 & 2 & 0 & 0 & 0 & 20 \\
\hline & Desapropriações & 0 & 1 & 1 & 0 & 0 & 0 & 2 \\
\hline & Com conflito & 2 & 2 & 0 & 0 & 0 & 0 & 4 \\
\hline & Sem informação & 159 & 189 & 77 & 3 & 2 & 5 & 435 \\
\hline & TOTAL & 379 & 412 & 157 & 6 & 6 & 11 & 971 \\
\hline \multirow{5}{*}{$\begin{array}{l}\mathrm{P} \\
\mathrm{A} \\
\mathrm{R} \\
\mathrm{T} \\
\mathrm{I} \\
\mathrm{C}\end{array}$} & Traspasse & 42,68 & 40,70 & 14,64 & 0,24 & 0,99 & 0,75 & 41,50 \\
\hline & Aforamento & 42,86 & 40 & 11,42 & 2,86 & 0 & 2,86 & 3,60 \\
\hline & Resgate & 26,39 & 50 & 19,44 & 1,39 & 0 & 2,78 & 7,41 \\
\hline & Compra e venda & 0 & 0 & 0 & 0 & 0 & 0 & 0 \\
\hline & $\begin{array}{l}\text { Ratificação de } \\
\text { posse }\end{array}$ & 60 & 30 & 10 & 0 & 0 & 0 & 2,06 \\
\hline \multirow{2}{*}{$\begin{array}{l}\mathrm{I} \\
\mathrm{P}\end{array}$} & Desapropriações & 0 & 50 & 50 & 0 & 0 & 0 & 0,20 \\
\hline & Com conflito & 50 & 50 & 0 & 0 & 0 & 0 & 0,41 \\
\hline \multirow{2}{*}{$\begin{array}{l}\mathrm{A} \\
C \mathcal{C} \\
\tilde{A} \\
\mathrm{O}\end{array}$} & Sem informação & 36,55 & 43,45 & 17,70 & 0,69 & 0,46 & 1,15 & 44,80 \\
\hline & TOTAL & 39,03 & 42,43 & 16,16 & 0,62 & 0,62 & 1,13 & 100,00 \\
\hline $\begin{array}{l}1 \\
\% \\
\text { ) }\end{array}$ & & & & & & & & \\
\hline
\end{tabular}

Fonte: Acervo fundiário da CODEM (2020).

Elaboração: Patrick Alves.

Nota: Na categoria "sem informação" foram incluídas as praças.

Dentre imóveis que foram transacionados, o domínio útil (traspasse e aforamento), cerca de $40 \%$ estão em bom estado de conservação e outros $40 \%$ apresentam condição regular. No caso da ratificação de posse esse percentual sobe, passando a boa conservação para $60 \%$ e a regular para $30 \%$, o que sugere uma tendência à melhoria da conservação, na medida em que se amplia o domínio da propriedade pelo proprietário. 
É significativa, ainda, a quantidade de imóveis regulares (415 unidades ou 42,73\%) e em mau estado de conservação (157 unidades correspondendo a 16,6\%), o que remete a um processo de degradação em curso. Os imóveis provenientes de Regate de Enfiteuse são os que apresentaram maiores percentuais em estado regular ou mau estado de conservação. Como os imóveis resgatados são, majoritariamente, residenciais, isso pode indicar que os moradores desses imóveis podem estar com dificuldades em arcar com os elevados custos inerentes à conservação de imóveis antigos.

Ao analisar a distribuição espacial das três classes de conservação consideradas na área de estudo (Figura 8), não foi possível identificar um padrão dominante relacionado à situação fundiária do imóvel.

Figura 8 - CHB - Bairro da Cidade Velha: Distribuição espacial dos lotes de acordo com o regime fundiário e o estado de conservação do imóvel, 2020.
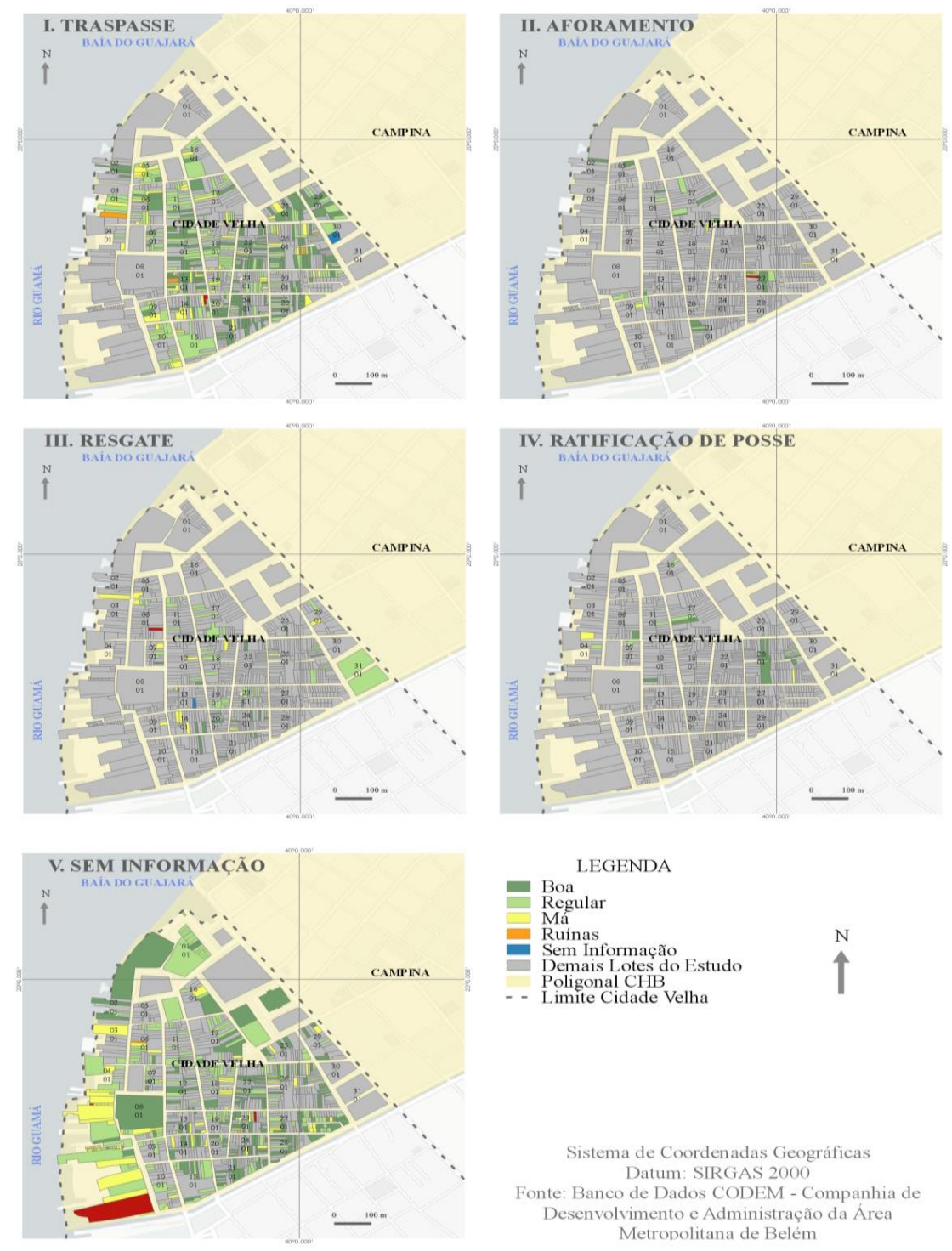

Fonte: Acervo da CODEM.

Elaboração: Ana Beatriz Macedo e Patrick Alves (2021) com base em informações levantadas por Patrick Alves. 


\section{CONCLUSÃO}

O presente artigo objetivou traçar um quadro da situação fundiária na área tombada do bairro da Cidade Velha, segmento de ocupação mais antiga do Centro Histórico de Belém, além de investigar a relação entre a situação da propriedade imobiliária e a as condições de ocupação dos lotes, os usos do solo e os estados de conservação dos imóveis.

Os dados levantados mostram que mais da metade da área de estudo $(55,85 \%)$ não possui informação fundiária segura e atualizada sobre a regularidade/irregularidade da propriedade. Em termos de quantidade de imóveis, 430 (44,28\%) dos 971 imóveis levantados não puderam ter a situação fundiária analisada no trabalho.

Os problemas das informações, aliados à falta de solução jurídica para o conflito entre União e Prefeitura sobre a gestão da posse dos Terrenos de Marinha e Acrescidos precisam ser equacionados, pois dificultam, sobremaneira, não apenas a gestão efetiva do patrimônio fundiário, como também, a gestão do patrimônio histórico tombado edificado, cujo licenciamento de obras de restauro e intervenção física requer documento de propriedade.

Quanto ao regime fundiário, os dados apresentados evidenciam que o traspasse é o tipo de alienação predominante entre os regimes fundiários regulares identificados na área de estudo. Isso significa que o poder público ainda é o principal proprietário do domínio pleno da grande maioria dos lotes, podendo promover o falecimento da enfiteuse de imóveis abandonados ou subutilizados e resgatar para si o domínio total desses lotes. Mostram também que, embora haja diversos imóveis em estado regular $(42,43 \%)$ e mau $(16,16 \%)$ de conservação, poucos são os lotes em construção $(0,20 \%)$, baldios $(0,62 \%)$ e em ruínas $(0,62 \%)$, o que evidencia que, apesar do estado de conservação do patrimônio edificado requerer atenção, as renovações dos imóveis decorrente da degradação (baldios e em ruínas) ou via demolição para construções novas edificações ainda são passíveis de controle.

Vale ressaltar que, dos imóveis com informações, nos casos de traspasse e aforamentos, observou-se a tendência de melhoria do estado de conservação ao ampliar o domínio da propriedade pelo proprietário, já nos casos de resgate, a maioria dos imóveis encontra-se em estado regular ou ruim de conservação.

Por fim, reconhece-se que, para reverter esse processo de degradação do CHB é preciso: solucionar o impasse entre SPU e Prefeitura com relação à gestão fundiária; ampliar e fortalecer o processo de regularização fundiária, promover incentivos e apoiar a manutenção das edificações, especialmente, as de uso habitacional voltadas para as camadas de menor renda da população moradoras na área de estudo, evitando, assim, os processos de gentrificação tão comuns verificados em áreas centrais de valor histórico na atualidade. 


\section{Notas}

${ }^{1}$ A poligonal definida na Portaria do IPHAN compreende 2.342 lotes situados nos bairros da Cidade Velha e da Campina, contudo, apresenta perímetro menor do que da área do CHB tombada pelo poder público municipal (IPHAN, 2018; MACEDO, 2020).

${ }^{2}$ Caracterizam a situação de irregularização fundiária, dentre outras: a ocupação em áreas irregulares, como faixas de canais, de proteção ambiental e de terceiros; a divergência de locação, ou seja, entre a área ocupada e a descrita no Termo, ou Registro Fundiário quem ocupa não é o proprietário e não tem relação de alienação/locação com o proprietário.

${ }^{3}$ Os BICs, produzidos por demanda solicitada na CODEM, se referem aos imóveis cadastrados por meio de alguma tipologia de processo, seja de Compra e Venda, Resgate, Concessão, dentre outros.

4 Aforamentos e Traspasses são termos fundiários de mesma natureza, sendo que o Traspasse é consequência do Aforamento, pois o Traspasse consiste apenas na transferência para outro foreiro (proprietário do domínio útil) do Termo de Aforamento.

${ }^{5}$ Essas categorias são assim definidas: Baldio - terrenos que não possuem nenhuma construção e nem estão sendo utilizados para algum fim; Recreio - terrenos públicos onde estão localizados os parques, as praças, etc.; Edificado - terreno que possui qualquer tipo de edificação; Em construção com lançamento predial terrenos onde havia uma edificação cadastrada nos arquivos da Prefeitura e seu proprietário demoliu-a e não informou a Prefeitura e no local já existe uma nova obra em andamento; Em construção sem lançamento predial - terreno onde está sendo construída qualquer obra e o lançamento de "IPTU" está como territorial; e Ruína - terreno onde se localiza uma edificação em péssimo estado de conservação, abandonada e já desabando.

\section{REFERÊNCIAS}

ALBUQUERQUE, Maria Claudia Bentes; RAMOS, Michelli Caldas. Regularização Fundiária Urbana como Instrumento de Direito à Moradia e direito à Cidade em Bens Imóveis Tombados Localizados em Centros Históricos: o caso do Bairro da Cidade Velha, em Belém (PA). Revista de Direito da Cidade, Rio de Janeiro, v. 13, n. 2, p. 921-953, 4 maio 2021. Trimestral. Disponível em: https://www.epublicacoes.uerj.br/index.php/rdc/article/view/49425. Acesso em: 16 jul. 2021.

BELÉM. Lei no 7.709 de 18 de maio de 1994. Dispõe sobre a preservação e proteção do Patrimônio Histórico, Artístico, Ambiental e Cultural do Município de Belém e dá outras providências. Belém: Câmara Municipal, 1994.

BERNARDINO, lana Ludermir; LACERDA; Norma. Centros históricos brasileiros: tensões entre a obsolescência imobiliária e a construção de novas espacialidades. Revista Brasileira de Estudos Urbanos e Regionais, v. 17, n.1, p. 61-74, abril 2015.

BORGES, Denilce Rabelo. As Institucionalidades na Gestão do Território: os limites das dominialidades territoriais sobre os terrenos de marinha em Belém - PA. 2012. 156 f. Dissertação (Mestrado) - Curso de Geografia, Instituto de Filosofia e Ciências Humanas, Universidade Federal do Pará, Belém, 2012. Cap. 4. Disponível em: http://repositorio.ufpa.br/jspui/bitstream/2011/8192/1/Dissertacao_Institucionalidades GestaoTerritorio.pdf. Acesso em: 26 jul. 2021.

BRASIL. Ministério das Cidades. Instituto do Patrimônio Histórico e Artístico Nacional. Implementação de ações em áreas urbanas centrais e cidades históricas: manual de orientação / Instituto do Patrimônio Histórico e Artístico Nacional (IPHAN) e Ministério das Cidades - Brasília-DF: IPHAN: Ministério das Cidades, 2011. 
BRASIL. Lei n. 5.172, de 25 de outubro de 1966. Dispõe sobre o Sistema Tributário Nacional e Institui Normas Gerais de Direito Tributário Aplicáveis à União, Estados e Municípios. Código Tributário Nacional. Brasília: Congresso Nacional, 1966.

BRASIL. 2002 Código Civil, Brasília: Congresso Nacional, 2002.

BRASIL. 1993 Lei no 8.666, de 21 de junho de 1993. Regulamenta o art. 37, inciso XXI, da Constituição Federal, institui normas para licitações e contratos da Administração Pública e dá outras providências. Brasília, 1993.

BRASIL. 2001 Medida Provisória no 2220, de 4 de setembro de 2001. Dispõe sobre a concessão de uso especial de que trata o § 10 do art. 183 da Constituição, cria o Conselho Nacional de Desenvolvimento Urbano - CNDU e dá outras providências. Brasília, 2001.

BRASIL. Decreto-Lei no 9.760/1946, dispõe sobre os bens imóveis da União e dá outras providências, Brasília: Congresso Nacional, 1967.

BRASIL. Decreto no 24.643, de 10 de junho de 1934, decreta o Código de Águas, Brasília: Congresso Nacional, 1934.

BRASIL. Lei no 9.636/1998, dispõe sobre a regularização, administração, aforamento e alienação de bens imóveis de domínio da União, altera dispositivos dos Decretos-Leis nos 9.760, de 5 de setembro de 1946, e 2.398, de 21 de dezembro de 1987, regulamenta o § 20 do art. 49 do Ato das Disposições Constitucionais Transitórias, e dá outras providências. Brasília: Congresso Nacional, 1998.

BRASIL. Lei no 10.257/2001, regulamenta os arts. 182 e 183 da Constituição Federal, estabelece diretrizes gerais da política urbana e dá outras providências. Brasília: Congresso Nacional, 2001.

BRASIL. Lei no 3.240, de 2015, dispõe sobre a administração, a alienação, a transferência de gestão de imóveis da União e seu uso para a constituição de fundos; altera a Lei no 9.636, de 15 de maio de 1998, e os Decretos-Lei no s 3.438, de 17 de julho de 1941, 9.760, de 5 de setembro de 1946, 271, de 28 de fevereiro de 1967, e 2.398, de 21 de dezembro de 1987; e revoga dispositivo da Lei no 13.139, de 26 de junho de 2015. Brasília, 30 dez. 2015. Disponível em: http://www.planalto.gov.br/ccivil_03/_Ato20152018/2015/Lei/l13240.htm. Acesso em: 22 jul. 2021.

BRASIL. Tribunal Regional Federal da 1ạ Região. Jurisprudência. Disponível em: https://trf1.jusbrasil.com.br/jurisprudencia/894073034/apelacao-civel-ac-ac-71404520094013900/relatorio-evoto-894073082?ref=juris-tabs. Acesso em: 22 jul.2021.

BRITO, Lilian Simone Amorim. Intervenção do centro histórico e a reorganização socio espacial do bairro da cidade velha/Belém-Pará. Dissertação - Universidade Federal do Pará. Instituto de Filosofia e Ciências Humanas. Belém, 2007.

CASTRO, Cleber Augusto Trindade; TAVARES, Maria Goretti da Costa Tavares. Processos de turistificação do espaço do patrimônio cultural: um estudo no Centro Histórico de Belém-PA. Turismo: Estudos \& Práticas (RTEP/UERN), Mossoró/RN, vol. 5, n. 1, p. 57-87, jan./jun. 2016.

CAVÉM, Mara. Centros históricos contemporâneos: mudanças de perspectiva na gestão caso de estudo de Lisboa e Bruxelas. 2007. Dissertação (Doutorado) - Curso de Mestrado em Geografia Humana, Planeamento Regional e Local, Universidade de Lisboa, Lisboa, 2007. 
CODEM. Companhia de Desenvolvimento e Administração da Área Metropolitana de Belém. Estatuto Social. (Artigo 38 e Parágrafo Único do Estatuto alterados pela 70a Assembleia Geral Extraordinária, realizada em 30 de abril de 2014, cujo registro na Junta Comercial do Estado do Pará - JUCEPA se deu em 11 de julho de 2014, sob o no 20000397987. Protocolo: 14/044242-1, de 24 de junho de 2014.) Disponível em: http://codem.belem.pa.gov.br/wp-content/uploads/2020/04/ESTATUTO-2014alterado.pdf. Acesso em: 10 jul. 2021.

CODEM. Companhia de Desenvolvimento e Administração da Área Metropolitana de Belém. Resolução no 005/2012, de 31 de julho de 2012. Suspende a regularização de domínio pleno de terrenos localizados em áreas consideradas pela CODEM como acrescidos de terrenos de marinha em Belém. Belém: Conselho de Administração, 2012.

COHAB. Companhia de Habitação do Estado do Pará. Oferta e demanda habitacional no Centro Histórico de Belém. Belém: Cohab-PA, 2009.

CORRÊA, Antônio José Lamarão. O Espaço das ilusões: Planos Compreensivos e Planejamento Urbano na Região Metropolitana de Belém. 1989. 339 f. Dissertação (Mestrado) - Curso de Curso Internacional de Mestrado em Planejamento do Desenvolvimento, Núcleo de Altos Estudos Amazônicos, Universidade Federal do Pará, Belém, 1989.

DURÁN, Ricardo Adrián V. Transformaciones de la imagen de una ciudad: repercusiones de la renovación urbana. Memorias: revista digital de historia y arqueología desde El Caribe, Colômbia, n. 6, p. 1-24, 2006.

ÉLERES, Paraguassú. Terrenos de Marinha: Terrenos Marginais dos Rios Navegáveis. São Paulo: Yan Graf Editora, 2014.

FERREIRA, Rachel Sfair da Costa. Para além das formas e das funções: preservação e gestão da paisagem do Centro Histórico de Belém (CHB) na perspectiva do espaço como instância e produção social, 317f. Tese (Doutorado) - Universidade Federal do Pará, Núcleo de Altos Estudos Amazônicos, Programa de Pós-Graduação em Desenvolvimento Sustentável do Trópico Úmido, Belém, 2014.

FERNANDES, Edésio; ALFONSIN, Betânia. Revisitando o Instituto do Tombamento. Belo Horizonte, Editora Fórum, 2010.

FISCHER, Luly Rodrigues da Cunha; CHAMBOULEYRON, Rafael Ivan; ROCHA, Ana Luisa Santos. Origem do Patrimônio fundiário da cidade de Belém. In. SILVA, Christian N. et al. Belém dos 400 anos: análises geográficas e impactos antropogênicos na cidade. Belém: GAPTA/UFPA, 2017, p. 217- 246.

FISCHER, Luly Rodrigues da Cunha. Diagnóstico fundiário e projetos de apuração do remanescente patrimonial. São Paulo: Acquerello, 2017, 173p. (relatório de pesquisa).

FONSECA, Cláudia Damasceno. Arraiais e vilas d'el rei: espaço e poder nas Minas setecentistas. Belo Horizonte: EdUFMG, 2011.

FORTE, Márcia Teixeira Filgueira. Trajetória do pensamento preservacionista e potencialidades para projetar no Centro Histórico de Belém-PA. 2015, 156 f. Dissertação (Mestrado) - Universidade Federal do Pará, Instituto de Tecnologia, Programa de Pós-Graduação em Arquitetura e Urbanismo, Belém, 2015. 
IPHAN. Instituto Patrimônio Histórico e Artístico Nacional. Gestão compartilhada do patrimônio cultural brasileiro - Belém/PA: Propostas para compatibilização da legislação urbanística para o Centro de Belém. Belém: IPHAN, nov. 2018 (slides em arquivo PowerPoint).

LACERDA, Norma et al. Dinâmica do Mercado Imobiliário nos Centros Históricos em tempos de globalização: os casos do Recife, Belém e São Luís (Brasil). Cadernos Metrópole, São Paulo, v. 20, n. 42, p.443-469, mai./jun. 2018. Disponível em: <https://revistas.pucsp.br/metropole/article/view/22369996.2018-4207/26367>. Acesso em: 18 jun. 2021.

LIMA, Davina Bernadete Oliveira. A percepção dos agentes do mercado imobiliário sobre a preservação e a legislação do Centro Histórico de Belém. 2015. 191 f. Dissertação (Mestrado) - Universidade da Amazônia, Programa de Pós-Graduação em Desenvolvimento e Meio Ambiente Urbano, Belém, 2015.

MACEDO, Ana Beatriz Fernandes de. Made in Asia: comércio asiático e morfologia urbana no Centro Histórico de Belém (PA). 2020. 194 f. Dissertação (Mestrado) - Universidade da Amazônia, Programa de Pós-Graduação em Desenvolvimento e Meio Ambiente Urbano, Belém, 2020.

MERCÊS, Simaia do S.; TOURINHO, Helena L. Z; LOBO, Marco Aurélio Arbage. Locação Social no Centro Histórico de Belém: uma abordagem introdutória. Caderno CRH. Salvador, v. 27, n. 71, p. 299-311, mai./ago., 2014.

MUNIZ, João de Palma. Patrimônios dos Conselhos Municipais do Estado do Pará. Paris/Lisboa: Aillud\&Cia, 1904.

LIMA, Davina Bernadete Oliveira. A Percepção dos Agentes do Mercado Imobiliário sobre a Preservação e a Legislação do Centro Histórico de Belém. 2015. 191 f. Dissertação (Mestrado) - Curso de Desenvolvimento e Meio Ambiente Urbano, Universidade da Amazônia, Belém, 2015.

MERCÊS, Simaia do Socorro Sales das; TOURINHO, Helena Lúcia Zagury; LOBO, Marco Aurélio Arbage. Locação Social no Centro Histórico de Belém: investigação introdutória. Caderno CRH, Salvador, v. 27, n. 71, p.299-311, jun. 2014.

NORAT, Roseane da Conceição Costa. Moradia como meio para Reabilitação de Áreas e Prédios Históricos. 2007. 237 f. Dissertação (Mestrado) - Curso de Programa de Pós-graduação em Arquitetura, Universidade Federal do Rio de Janeiro, Rio de Janeiro, 2007.

PENTEADO, A. R. (1968). Belém: estudo de geografia urbana. Coleção Amazônica, Série José Veríssimo. Belém, Universidade Federal do Pará.

TOURINHO, Andréa de Oliveira. O estudo do Centro e da Centralidade Urbanos em São Paulo. Desígnio, São Paulo, v. 3, p.85-97, mar. 2005.

Do Centro às Novas Centralidades: uma trajetória de permanências terminológicas e rupturas conceituais. In: GITAHY, Maria Lucia C.; LIRA, José T. C. Cidade: Impasses e Perspectivas. São Paulo: Fau/Annablume/Fupam, 2007. p. 11-28.

TOURINHO, Helena Lúcia Zagury; LIMA, Davina Bernadete Oliveira. planos urbanos e Centro Histórico de Belém. Cadernos de Arquitetura e Urbanismo, v. 22, n. 30, p. 51-52, 2015. 
TRINDADE JR., Saint-Clair Cordeiro da; AMARAL, Márcio Douglas. Reabilitação urbana na área central de Belém-Pará: concepções e tendências de políticas urbanas emergentes Revista Paranaense de Desenvolvimento, Curitiba, n.111, p.73-103, jul./dez. 2006.

VILLAÇA, Flávio. Reflexões Sobre as Cidades Brasileiras. São Paulo: Studio Nobel, 2012.

Trabalho enviado em 27 de julho de 2021 Aceito em 24 de agosto de 2021 